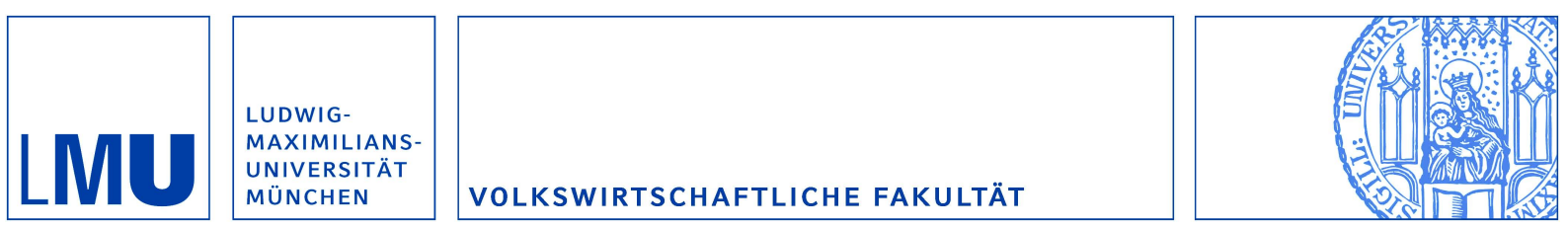

Englmaier, Florian und Stowasser, Till:

Electoral cycles in savings bank lending

Munich Discussion Paper No. 2014-14

Department of Economics

University of Munich

Volkswirtschaftliche Fakultät

Ludwig-Maximilians-Universitä† München

Online at https://doi.org/10.5282/ubm/epub.20845 


\title{
Electoral cycles in savings bank lending*
}

\author{
Florian Englmaier ${ }^{\dagger} \quad$ Till Stowasser ${ }^{\ddagger}$
}

May 14, 2014

\begin{abstract}
We provide causal evidence that German savings banks - where local politicians are by law involved in their management - systematically adjust lending policies in response to local electoral cycles. The different timing of county elections across states and the existence of a control group of cooperative banks - that are very similar to savings banks but lack their political connectedness - allow for clean identification of causal effects of county elections on savings banks' lending. These effects are economically meaningful and robust to various specifications. Moreover, politically induced lending increases in incumbent party entrenchment and in the contestedness of upcoming elections.
\end{abstract}

Keywords: Bank lending cycles, political business cycles, political connectedness, public banks, government ownership of firms

JEL classification: G21, D72, D73

*We are grateful to Daniel Carvalho, Georg Gebhardt, Dirk Jenter, Francis Kramarz, David Laibson, Niko Matouschek, Monika Schnitzer, Andrei Shleifer, Joachim Winter, and seminar audiences at UCLA, the University of Munich, the 2012 Royal Economic Society Conference in Cambridge, the 2012 European Economic Association Conference in Málaga, the 2012 American Law and Economics Conference in Stanford, and the University of Zurich for comments and suggestions. Quirin Hausmann, Thomas Hattenbach, Nikolaos Karygiannis, Johannes Kümmel, and Kirill Lindt provided excellent research assistance. This research was partially funded through DFG grant SFB/TR-15.

${ }^{\dagger}$ University of Munich, florian.englmaier@econ.lmu.de

‡University of Munich, till.stowasser@econ.lmu.de 


\section{Introduction}

Government control over enterprises is widespread across the world. While early authors, following Atkinson and Stiglitz (1980), argued that state-ownership is a second-best optimal policy to overcome market failure, the more recent literature, following Shleifer and Vishny (1994), opposes this view: It argues that politicians use these firms to extract private rents for themselves or their supporters, thereby creating rather than eliminating social inefficiencies. Government control is particularly prominent in the banking sector whose role in the recent financial crises has become the subject of increased scrutiny (see for example Schwartz, 2009). For reasons like these, it is important to understand the consequences of government control over financial institutions.

There is already evidence for rent extraction in the public banking sector (see La Porta et al. (2002); Sapienza (2004); Dinç (2005); Khwaja and Mian (2005); Cole (2009); Carvalho (2012)) but it is restricted to developing and emerging countries with notoriously weak institutions. In this paper, we present causal evidence for substantial distortions in the lending behavior of governmentcontrolled banks in a highly developed country with a reputation for efficient institutions: Lending policies of German savings banks closely track the local electoral cycle. ${ }^{1}$ Their aggregate credit stock systematically increases by roughly $2 \%$, corresponding to an average of EUR 56.9 million, in the run-up to local elections. Assuming an average credit tenure of 3 to 4 years, this translates into a $6 \%$ to $8 \%$ increase in newly extended loans.

These results are robust to various empirical specifications and in line with the hypothesis that local savings banks serve the interests of county-level politicians who push for more lavish pre-election lending in hopes of boosting economic conditions, the mood of the electorate, and, ultimately, their re-election prospects. ${ }^{2}$ Considering that savings banks constitute an important pillar of the German banking system and that they are the main lender to private customers

\footnotetext{
${ }^{1}$ While there are various ways to measure the quality of institutions, the Transparency International Corruption Index is a very prominent example. Germany ranks well in the least corrupt decile of this measure (see: http://www.transparency.org).

${ }^{2}$ Peltzman (1987) and Wolfers (2007) document that economic conditions are important for re-election prospects and Smart and Sturm (2007) provide evidence that politicians react to reelection incentives.
} 
and small to medium sized businesses (SMEs), it is worrisome to find their policies substantially distorted. ${ }^{3}$

The political tinkering that we document is possible due to a specific institutional feature of the German banking sector: For historical reasons, and with very few exceptions, each German county is matched with one savings bank that is effectively controlled by local politicians. In particular, key supervision functions in the bank's management, specifically in credit decisions, are filled with county politicians. Taking advantage of a high degree of variation in electoral timing, we achieve clean identification of causal effects: Local elections in Germany are synchronized at the state level but not across states and in general are held on different days than state elections. In addition, German cooperative banks - which have the same regional organization and a similar business model as savings banks, but are not politically controlled - are a well-suited control group. Hence, we are able to exploit both intertemporal variation, as banks are repeatedly treated with an election over the course of time, and cross-sectional variation, as in any given year some banks are treated and others are not. Econometrically, we conduct difference-in-difference (DD) as well as triple-difference (DDD) estimation embedded in a fixed-effects panel setup. Importantly, we demonstrate that pre-election increases in lending are not demand-driven, as they do neither occur prior to state elections (where standard political business cycle policies might be in place and spur credit demand) nor for cooperative banks (that should be similarly affected by any increase in credit demand).

Our rich, in large parts hand-collected, data combines unusually comprehensive bank data (both with respect to its cross-section and time series dimensions) with detailed information on German county elections that has, thus far, not been available for research. This degree of detail allows us to study the role of polit-

\footnotetext{
${ }^{3}$ In 2011, the more than 400 German savings banks employed 245,969 people and controlled total assets of EUR 1,098 billion. In the EUR 228.2 billion consumer credit market, the $25 \%$ market share of savings banks is comparable to a $23 \%$ share of cooperative banks and much larger than the $7 \%$ share of all major commercial banks, such as Deutsche Bank or Commerzbank. In the substantially larger market for corporate loans (including credit to the self-employed), which totaled EUR 1,356 billion, savings banks had a market share of $24 \%$, whereas cooperative banks held $15 \%$, and all large commercial banks $13 \%$ of the market. Apart from these aggregate numbers, some savings banks are also of impressive size individually. For instance, in 2011 Stadtsparkasse Munich extended credit of EUR 9.6 billion. (All numbers taken from the 2011 financial report of the German federal savings bank association.)
} 
ical competition in keeping electoral distortions of lending in check. We show that excess pre-election lending is particularly pronounced in districts that are historically tightly controlled by an incumbent party (increasing the ability to influence bank policies) but that face a close upcoming election (providing the incentive to distort lending). In those counties that were historically entrenched but now face close races the extent of politically induced excessive lending increases to $5.6 \%$ of the aggregate credit stock while the excess lending is hardly present in counties that were historically not particularly entrenched and that do not face tight races. This suggests that not only potential political competition per se - guaranteed by a strong institutional environment - but also the intensity of actual electoral competition is decisive in determining the scope of political rent-extraction.

The above results are extremely robust. They remain significant and substantial using a wide range of controls (like total assets and capital ratios at the bank level or local GDP and population levels at the county level), using different definitions of the dependent variable, allowing for alternative error structures, and varying the sample composition by excluding different subsets of years, banks, or states.

The paper relates to several literatures. The first is the theory of (opportunistic) political business cycles (PBC) pioneered by Nordhaus (1975) and MacRae (1977), which describes politicians' incentives to enact expansionary fiscal policies shortly before elections to boost their own popularity, only to offset them with contractionary policies afterwards. This theory has received empirical support in numerous studies (Alesina et al., 1997; Akhmedov and Zhuravskaya, 2004; Mitchell and Willett, 2006; Bertrand et al., 2007; and Schneider, 2010 among others).

A more immediate connection exists to a strand of the finance literature that documents distortions in the behavior of government-controlled banks. Rather than directly implementing policies that further their interests, politicians use financial institutions as a vehicle to this end. La Porta et al. (2002) find that government ownership of banks is most prominent in low-income countries with underdeveloped financial systems, generally inefficient governments, and poor protection of property rights. Moreover, government ownership of banks is associated with lower growth of per capita income. Sapienza (2004) studies the effects of government ownership on bank lending in Italy and shows that, con- 
trolling for firm characteristics, state-owned banks charge lower interest rates than private banks. Furthermore, the effect on interest rates is more pronounced if the political party affiliated with a given firm is stronger in the area in which the firm is borrowing. Similarly, Khwaja and Mian (2005) find that politically connected firms in Pakistan have easier access to credit from government banks. Dinç (2005) shows that the lending behavior of public banks in developing countries depends on the timing of elections. Cole (2009) finds that lending for agricultural loans by government-owned banks in India is related to the electoral cycle, and that the largest increases in lending occur in districts in which elections are close. Carvalho (2012) documents that Brazilian firms eligible for government bank lending expand employment in politically contested regions prior to elections by shifting employment from other regions. Yet, given that all of this affirmative evidence is limited to countries with weak institutional environments, this paper is the first to provide clean causal evidence for distorted lending policies in a country that is often cited as an epitome of political efficiency. ${ }^{4}$

The remainder of this paper is organized as follows: The institutional background is described in section 2. Section 3 specifies the research hypotheses and testable predictions. Section 4 discusses merits and limitations of our data while methodological issues and the identification strategy are presented in section 5. Section 6 contains the empirical results, and section 7 reports robustness tests. Section 8 concludes.

\section{Institutional background}

This section provides the institutional details relevant for evaluating the identification strategy. We lay out the case for why savings banks are a prime example of politically controlled firms, why cooperative banks are a suitable control group, and how the German electoral system allows to cleanly estimate causal effects of elections on bank lending.

\footnotetext{
${ }^{4}$ In fact, Dinç (2005) fails to find an electoral effect on lending in developed economies. The discrepancy between our results and those of Dinç is likely explained by our focus on county (instead of general) elections, reflecting that in the German case, political influence on banks is at the local and not the federal level.
} 


\subsection{The German electoral system}

Germany has a federal system with three layers of government: the federal state, the 16 states (Bundesländer), and 399 county districts (consisting of 292 rural counties (Landkreise) and 107 urban municipalities (Kreisfreie Städte)). Each layer has specific powers and responsibilities as well as separate legislative bodies, which are elected in regular intervals: every 4 years at the federal level, every 4 to 5 years at the state level and every 4 to 6 years at the county level. Since control over savings banks is exerted by county-level governments (see section 2.2 below), we focus on the latter class of elections.

Each county district has its own legislative body. While elections of these local parliaments are coordinated at the state level - that is, within a state they all take place on the same election day - they provide a great deal of variation in electoral timing. For one, county election dates generally deviate from dates of federal or state elections, i.e. as a rule they are not held on the same day. Moreover, county election dates differ across states, neatly dispersing electoral events over several years. Variation is further increased by the fact that the intervals between elections are not the same for all states: While in most cases elections are held every 5 years, legislative periods are shorter for Bremen and Hamburg (4 years) and longer for Bavaria (6 years). In addition, the electoral laws of Berlin and Schleswig-Holstein saw a change in the early 1990s, replacing a 4-year with a 5-year interval. In all states the electoral system is one of proportional representation with a minimum vote share requirement.

\subsection{The German banking system}

The German banking systems consists of three pillars (Drei-Säulen-Modell): private banks, savings banks (Sparkassen), and cooperative banks (Genossenschaftsbanken). Whereas private banks are best described as profit-maximizing firms, savings banks and cooperative banks are legally bound to also pursue welfare enhancing policies, in particular within the region they operate in. According to the German Central Bank (Deutsche Bundesbank), in 2011 there were roughly 1,100 cooperative banks, 426 savings banks and 218 private banks operating in Germany. Because savings banks and cooperative banks are the focus of the empirical analysis, these two bank types will be described in more detail. 


\section{Savings banks}

As of 2011, German savings banks held combined assets of well over one trillion EUR, of which 677 billion EUR represent lending to the private sector. This translates into market shares of $24 \%$ and $25 \%$ of all lending to businesses and private households, respectively. ${ }^{5}$ Much like the German government system, the structure of the German savings bank sector is one of three levels: On the local level there are the individual savings banks. At the state level there are associations (Sparkassen- und Giroverbände) to realize economies of scale for operative tasks. On the federal level, a further association (Deutscher Sparkassen- und Giroverband (DSGV)) is primarily responsible for representing the interests of savings banks towards the federal government and international institutions. All relevant decisions regarding the business policies of an individual savings bank are autonomously taken at the local level. Due to their local structure, and imposed by law, the savings banks' operations have a strong focus on the region they operate in (Regionalprinzip). Their main clientele are private customers and local businesses. In particular, savings banks are the main creditor for SMEs - the so called Mittelstand - that are traditionally considered the backbone of the German economy. ${ }^{6}$

The first "modern" savings banks in Germany were founded by local governments in the late 18th century in Northern Germany. Initially, the number of savings banks increased from 300 (in 1836) to more than 3,000 (in 1913). Gradually, this number was reduced when for efficiency reasons neighboring local institutions merged (for more details see Guinnane, 2002). Today there exist 426 savings banks, roughly matching each county with one savings bank. ${ }^{7}$

Given this historic origin, local governments still hold significant sway over the management of savings banks, in particular their lending activities: ${ }^{8}$ Coun-

\footnotetext{
${ }^{5}$ All numbers taken from the 2011 financial report of the German federal savings bank association

${ }^{6}$ According to the German Institute of SME Research (Institut für Mittelstandsforschung Bonn), roughly $38 \%$ of the entire German business volume is generated by SMEs and they employ almost two thirds of the German work force.

${ }^{7} \mathrm{~A}$ slight mismatch between the number of electoral districts and the number of savings banks is explained by temporally imperfect synchronization of the merging of districts and the merging of savings banks.

${ }^{8}$ An additional reason for close governmental control lies in the fact that German law installs public guarantee obligation (Gewährträgerhaftung) for public institutions. This rule provides that the creditor is going to be reimbursed by the government in case the public institution is not
} 
ties have the formal right to send representatives into the board of directors (Sparkassenverwaltungsrat) and the central credit committee (Kreditausschuss) of the respective savings bank. As a result, their members are to a large degree composed of county parliament members, roughly reflecting the relative political powers in the electoral district. On top of that, the chairmen of both chambers is, as a rule, the political representative of the respective county. By law, the directors are not bound by an imperative mandate but are supposed to only consider the greater good of the savings bank. While this form of political representation may plausibly foster the creation of informal but meaningful ties between policymakers and bank executives, some of the leverage is even of statutory nature: Besides having general authority to establish guidelines, board members have substantial influence over credit decisions that exceed the authority of the savings bank's management, as the board of directors or the central credit committee have to vote on credits that are either large in size or considered rather risky (see Schlierbach, 2003 and Güde, 1995).

\section{Cooperative banks}

The first cooperative banks in Germany were founded by Franz Hermann SchulzeDelitzsch und Friedrich Wilhelm Raiffeisen in the middle of the 19th century. They are organized as cooperatives, making each customer also a "member" of the bank. Much like savings banks, they are locally organized, with one to three cooperative banks in every county. Their main clientele are private customers and local businesses.

Most local cooperative banks are organized in a federal association of cooperative banks (Bundesverband der Deutschen Volksbanken und Raiffeisenbanken). Cooperative banks are not covered by the public guarantee obligation but their federal association provides an insurance fund to provide deposit guarantees. Since cooperative banks are independent from governmental institutions and are not protected by public guarantees, politicians have no formal way to influence cooperative banks' business policies.

able to live up to its contractual obligations. Having been founded by the respective counties, German savings banks were considered public institutions, and were covered by a municipal public guarantee obligation. The European Court of Justice deemed this an obstacle to competition in retail banking and savings banks were exempted from public guarantee obligation as of July 19, 2005. See Gropp et al. (2011) or Fischer et al. (2011) for studies on the effect of this decision on savings banks' and Landesbanks' risk taking, respectively. 
Cooperative banks constitute a well-suited control group as they have a similar regional structure as savings banks, cater to a comparable clientele, and have an almost identical business model (Engerer, 2006 and Hakenes and Schnabel, 2006) $)^{9}$ - but they are exempted from the direct control local politicians hold over savings banks' business policies.

Note that, in stark contrast to this, private banks differ greatly from savings banks, rendering them unsuitable as a control group. First, their business model solely focuses on profit-maximization and is unrestricted by welfare considerations. Second, their outreach is usually not confined to a specific region. Third, their client structure is much less rooted in private households and small firms. Fourth, and most importantly from a practical point of view, their spatial representation does not consist of independent regional units but of mere branches that are legally part of operational headquarters and for which no disaggregated data is available to researchers.

\section{Main hypothesis and testable predictions}

The main hypothesis this paper seeks to test is whether local savings banks expand lending in the run-up to elections. Local politicians would want to induce banks to do so in hopes of swaying their re-election prospects. As described in section 2, the institutional environment creates the ability to influence lending as it installs local politicians as members and even chairs of the board of directors of savings banks. Given this board's substantial authority that goes much beyond rubber-stamping decisions made by the bank's management, politicians have an immediate path to affecting the lending activities of their local savings bank.

Besides this general opportunity, there is also an incentive for policymakers to artificially expand lending in their districts: As established in the literature (see, for example, Smart and Sturm, 2007), politicians care about re-election and (perceived) economic conditions are an important determinant for the prospects of winning another term (see Peltzman, 1987 and Wolfers, 2007). Pushing for more

\footnotetext{
${ }^{9}$ Comparing the regulating laws (our translation) describing the purposes of cooperative banks (here for Volksbanken) and savings banks (here for Baden-Württemberg) highlights that they share basically the same objectives:

§1(1) Genossenschaftsgesetz: "[...] to foster the income or the enterprise of the members [...]" §6(1) Sparkassengesetz Baden-Württemberg: “[...] to ensure the provision with money and credit in their region in particular for SMEs [...]"
} 
generous lending policies is one channel through which politicians can spur the local economy: Constituents will be more satisfied when they are not troubled by credit rationing and loans to SMEs may be paramount for the creation or preservation of employment in the district. Also not directly affected voters will, ceteris paribus, interpret better economic conditions as indicative for better economic policies implemented by incumbent politicians. The legally mandated regional focus of savings banks helps local politicians to target the benefits of these policies as borrowers will almost certainly live - and vote - in the region. Moreover, the described channel is attractive to the politician as the potential costs of this intervention (for instance, lower quality and, hence, higher default rates for the marginally granted credits) are deferred until the loans in question mature, that is, the negative fallout is not instantly visible and may in fact never be traced back to the responsible politicians.

Following the argument made above, lending increases should be exclusive to savings banks whereas financial institutions that lack the described political connection - as is the case for cooperative banks - should not be affected. Similarly, excess lending should not occur in the run-up to elections of state parliaments, where local politicians are not exposed to the risk of displacement. ${ }^{10}$ Using cooperative banks as a control group and running placebo tests with state elections allows us to distinguish politically motivated lending from an increase in demand for credit in response to real economic growth around election years, caused, for example, by traditional political spending cycles. These traditional expansionary policies should equally affect cooperative bank lending and should also be present for elections of higher levels of government. ${ }^{11}$

In terms of the timing of bank lending distortions, politically motivated lending should be focused on election seasons rather than equally distributed throughout the legislative period. This way, any negative short-term consequences (e.g., higher default rates for the marginal loans) of expanding credit are unlikely to be visible before the election date. Moreover, if voters are myopic, political gain

\footnotetext{
${ }^{10}$ Recall that it is local politicians who are granted membership in the bank's board of directors. While a few exceptions from this rule (with members of state parliaments being granted access as well) exist, any potential effect should be considerably weaker than that of county elections.

${ }^{11}$ Note that German states control a substantially larger share of public spending as compared to counties (in 2011, EUR 319 billion vs. EUR 195 billion). Hence, the absence of a state election effect further strengthens the case that credit expansion is not driven by standard expansionary pre-election policies.
} 
is maximal if the instrument is applied in the run-up to elections. Importantly, any lending increase should not extend to post-election periods - at least until the next electoral lending cycle starts unfolding - since incentives to allure voters vanish once the polls are closed.

Finally, the strength of any election effect should depend in two partly countervailing ways on the degree of electoral competition politicians face in their district:

On the one hand, the ability of politicians to influence savings bank lending should be curbed by high general electoral competition that has led to close elections in the past. The rationale for this argument is one of entrenchment: A competitive political environment will be reflected in a balanced composition of the bank's board of directors, reducing the likelihood of collusion among board members who represent rivaling political parties. As a result, regular changes in power and slim majorities in the past would limit the scope of electoral lending cycles. On the other hand, the second effect of electoral competition - shaping the incentive to distort bank operations - depends of the contestedness of current elections. Politically motivated lending is presumably costly for savings banks as extramarginal loans are likely to be of worse quality and carry higher risks of default. Hence, incumbent politicians should not make much use of this distorting instrument unless they face a close election.

Based on these general arguments we formulate four specific testable predictions:

Prediction 1: Election effect. In the run-up to county elections, local savings banks systematically increase lending. At the same time, there is no increase in pre-election lending for cooperative banks that are very similar to savings banks but are not politically controlled.

Prediction 2: Election type. Elections at the state level have no systematic impact on credit extension since politicians from this level of government are not institutionally connected with local savings banks.

Prediction 3: Lending cycle. Politically motivated increases in lending occur exclusively in the run-up to elections. After elections, lending quickly returns to its normal level before a new lending is initiated.

Prediction 4: Electoral competition. The electoral lending cycle is stronger in districts with high levels of entrenchment of the incumbent party and high 
levels of current electoral contestedness, increasing opportunities and incentives, respectively, for politicians to distort bank policies.

Whether these predictions are consistent with the data is investigated in section 6. Before turning to this analysis, however, we continue with the description of the data and discuss some caveats concerning the feasibility of testing these predictions with the information at hand.

\section{Data}

We use a novel, in large parts hand-collected, dataset that combines information from multiple sources. The observational units are German savings and cooperative banks. This bank data is merged with information on county and state elections as well as with macroeconomic and demographic data on the county level. Overall, our working sample includes data for 1,735 banks that operated in 14 out of 16 German states, during the years between 1987 and $2009 .{ }^{12}$

\subsection{Bank data}

The source of our bank data is Hoppenstedt, a business data provider that hosts the largest commercial database for balance sheets and annual reports in Germany. The main advantage of Hoppenstedt, compared to similar commercial databases such as Bankscope, are the ample dimensions (both cross-sectionally and intertemporally) the sample provides: It covers virtually all savings banks and a large fraction of cooperative banks that operated in Germany between 1987 and 2009. ${ }^{13}$ The data covers a total of 521 savings banks (8,626 bank-year observations) and 1,214 cooperative banks (10,351 bank-year observations). ${ }^{14}$ Note that these numbers include a sizable number of banks that exited or entered the sample due to bank mergers. The average time savings banks remain

\footnotetext{
${ }^{12}$ We leave out the formerly GDR states of Saxony and Saxony-Anhalt which experienced multiple territorial reforms post-unification in 1990 that radically altered the composition of electoral districts. See section 4.2 below for details.

${ }^{13}$ We ran several internal consistency checks to ensure that the Hoppenstedt data be of comparable quality to that of Bankscope.

${ }^{14}$ Eight savings banks in our sample - the so-called Freie Sparkassen - are incorporated and do not grant politicians access to their governing boards. They are treated as cooperative banks in the main specification. Robustness analysis not presented here, shows that none of the results is driven by this recoding.
} 
in the sample is 17 years, whereas the average cooperative bank is only observable for roughly 9 consecutive years. This reflects that our panel is considerably less balanced for cooperative banks, as a large fraction is only covered by the sample since the early 2000s. To ensure that the results are not driven by these sample characteristics, we perform robustness checks by varying the degree of panel balancedness in section 7.3.

All information is taken from official balance sheets. The key variables are the bank's overall lending position, total assets, and the capital ratio. All monetary positions are deflated and measured in 1995 EUR. A look at the panel characteristics reveals that for all items between-variation is substantially greater than within-variation.

\subsection{Election data}

A database that combines information on German county elections in any comprehensive way does not exist. Even at the state-level, the collection of local electoral data is the clear exception. For this reason, we created a unique dataset by collecting all necessary information ourselves. To this end, we contacted regional statistical offices, the respective counties, and historical archives all over Germany. As a result of this labor intensive project, we have collected data for all 399 German counties. Given that the states of Saxony and Saxony-Anhalt, that had belonged to the GDR and enter the data only in 1990, experienced multiple territorial reforms that radically altered the composition of electoral districts, we dropped observations of these two states, reducing the number of counties with usable information to 373. This election data covers the years between 1970 and 2009 for the 11 western states and the post-reunification years between 1990 and 2009 for the five eastern states. Yet, since the political data is merged with the aforementioned bank data, the maximum interval for analysis is effectively reduced to 1987-2009. During this time span, the relative states held 4 to 7 elections of local legislative bodies. The dataset contains information on election dates, election results (measured in vote shares), the names and party affiliations of incumbents and election winners, and whether there was a change in power. To enable empirical testing of prediction 2 , we have also added dates and outcomes of state elections. 


\subsection{District data}

Finally, to warrant better control for confounding factors and to increase statistical precision, the sample is augmented with time-varying macroeconomic and demographic information at the district level, which are available at the German Federal Statistic Office (Statistisches Bundesamt Deutschland). These include population size, GDP, unemployment, public spending and expenditure, public debt, as well as firm creation, closures and bankruptcies. Once again, all monetary values are converted to 1995 EUR. Available time spans vary significantly among these variables so that the addition of certain control variables results in significant loss of sample size. The longest time series are available for GDP, population size and unemployment, spanning from the early 1990s to 2009. The collection of the other variables by the Statistic Office sets in considerably later. For these reasons, the effective time-span covered by the main econometric specification presented in section 5 covers the years between 1993 and 2009, whereas time spans of deviating length are analyzed for robustness in section 7.3.

\subsection{Descriptive statistics}

Summary statistics of variables used in the analysis are presented in table 1 . Overall, our data is substantially right-skewed, which is why the main empirical specification presented below makes use of log-transformed data. As is evident from panel A, savings banks are on average larger than their cooperative counterparts. Judging from the ratio of loans and total assets, both bank types clearly set their business focus on lending operations: The average loan position of savings banks makes up $70 \%$ of the entire balance sheet, while that number is slightly higher for cooperative banks, which devote almost $73 \%$ of their operations to providing credit. Furthermore, the capital ratio seems to be mildly, but systematically, larger for cooperative banks.

A look at panel B reveals that counties in Baden-Württemberg and Bavaria are clearly dominated by conservative parties - Bavaria's Christlich-Soziale Union (CSU) and its sister party, Christlich Demokratische Union (CDU), which competes in the rest of Germany - whereas the other states see a closer gap between the main political rivals: Germany's largest left-of-center party, Sozialdemokratische Partei Deutschlands (SPD), generally fares very poorly and incumbent dominance appears to be much stronger in the two aforementioned states, suggesting a 
Table 1. Variables used for analysis

Summary statistics

\begin{tabular}{|c|c|c|c|c|c|c|c|c|c|c|c|c|c|c|c|}
\hline Variables & Total & BW & BV & $\mathrm{BE}$ & BB & BR & HA & HS & LS & MW & NW & $\mathrm{RP}$ & SL & $\mathrm{SH}$ & TH \\
\hline \multicolumn{16}{|c|}{ Panel A: Banks } \\
\hline Bank-year obs. & 18,977 & 3,722 & 4,414 & 46 & 260 & 85 & 81 & 1,658 & 1,907 & 126 & 3,983 & 1,274 & 337 & 692 & 392 \\
\hline \multicolumn{16}{|l|}{ Savings banks } \\
\hline - No. of banks & 521 & 73 & 103 & 1 & 14 & 3 & 2 & 53 & 60 & 6 & 123 & 40 & 9 & 19 & 18 \\
\hline - Total assets & $\begin{array}{l}1.908 \\
(2.176)\end{array}$ & $\begin{array}{l}2.295 \\
(1.920)\end{array}$ & $\begin{array}{l}1.658 \\
(1.579)\end{array}$ & $\begin{array}{l}75.091 \\
(33.015)\end{array}$ & $\begin{array}{l}1.589 \\
(1.589)\end{array}$ & $\begin{array}{l}2.669 \\
(2.894)\end{array}$ & $\begin{array}{c}9.662 \\
(13.181)\end{array}$ & $\begin{array}{l}2.453 \\
(3.086)\end{array}$ & $\begin{array}{l}1.635 \\
(1.738)\end{array}$ & $\begin{array}{l}1.293 \\
(1.024)\end{array}$ & $\begin{array}{l}2.157 \\
(3.045)\end{array}$ & $\begin{array}{l}1.480 \\
(0.799)\end{array}$ & $\begin{array}{l}1.943) \\
(1.603)(\end{array}$ & 1.834 & $\begin{array}{l}1.083 \\
(0.531)\end{array}$ \\
\hline - Loans & $\begin{array}{l}1.327 \\
(1.580)\end{array}$ & $\begin{array}{l}1.588 \\
(1.332)\end{array}$ & $\begin{array}{l}1.148 \\
(1.078)\end{array}$ & $\begin{array}{l}56.127 \\
(27.409)\end{array}$ & $\begin{array}{l}0.721 \\
(0.633)\end{array}$ & $\begin{array}{l}2.069 \\
(2.362)\end{array}$ & $\begin{array}{c}7.726 \\
(10.742)\end{array}$ & $\begin{array}{l}1.726 \\
(2.170)\end{array}$ & $\begin{array}{l}1.203 \\
(1.332)\end{array}$ & $\begin{array}{l}0.729 \\
(0.580)\end{array}$ & $\begin{array}{l}1.509 \\
(2.272)\end{array}$ & $\begin{array}{l}1.0371 \\
(0.605)\end{array}$ & & 1,423 & $\begin{array}{l}0,575 \\
(0.344)\end{array}$ \\
\hline - Capital ratio & $\begin{array}{l}0.046 \\
(0.010)\end{array}$ & $\begin{array}{l}0.043 \\
(0.008)\end{array}$ & $\begin{array}{l}0.048 \\
(0.012)\end{array}$ & $\begin{array}{l}0.030 \\
(0.030)\end{array}$ & $\begin{array}{l}0.038 \\
(0.008)\end{array}$ & $\begin{array}{l}0.049 \\
(0.007)\end{array}$ & $\begin{array}{l}0.046 \\
(0.008)\end{array}$ & $\begin{array}{l}0.045 \\
(0.009)\end{array}$ & $\begin{array}{l}0.050 \\
(0.010)\end{array}$ & $\begin{array}{l}0.039 \\
(0.007)\end{array}$ & $\begin{array}{l}0.047 \\
(0.008)\end{array}$ & $\begin{array}{l}0.0460 \\
(0.010)\end{array}$ & $\begin{array}{l}0.0 \\
(0.0\end{array}$ & & $\begin{array}{l}0.039 \\
(0.009)\end{array}$ \\
\hline \multicolumn{16}{|c|}{ Cooperative banks } \\
\hline - No. of banks & 1,214 & 250 & 342 & 1 & 11 & 3 & 3 & 97 & 135 & 7 & 206 & 77 & 18 & 44 & 17 \\
\hline - Total assets & $\begin{array}{l}0.883 \\
(4.261)\end{array}$ & $\begin{array}{l}0.645 \\
(0.676)\end{array}$ & $\begin{array}{l}0.616 \\
(2.319)\end{array}$ & $\begin{array}{l}8.563 \\
(2.798)\end{array}$ & $\begin{array}{l}0.297 \\
(0.087)\end{array}$ & $\begin{array}{l}0.469 \\
(0.154)\end{array}$ & $\begin{array}{l}0.956 \\
(0.346)\end{array}$ & $\begin{array}{l}0.753 \\
(0.878)\end{array}$ & $\begin{array}{l}0.448 \\
0.397)\end{array}$ & $\begin{array}{l}0.345 \\
(0.131)\end{array}$ & $\begin{array}{l}0.900 \\
(2.379)\end{array}$ & $\begin{array}{l}0.5550 \\
(0.627)\end{array}$ & $\begin{array}{l}0.610 \\
(0.625)\end{array}$ & 0.75 & $\begin{array}{l}0.331 \\
(0.159)\end{array}$ \\
\hline - Loans & $\begin{array}{l}0.650 \\
(3.248)\end{array}$ & $\begin{array}{l}0.478 \\
(0.460)\end{array}$ & $\begin{array}{l}0.462 \\
(1.822)\end{array}$ & $\begin{array}{l}6.376 \\
(1.861)\end{array}$ & $\begin{array}{l}0.166 \\
(0.051)\end{array}$ & $\begin{array}{l}0.352 \\
(0.117)\end{array}$ & $\begin{array}{l}0.728 \\
(0.258)\end{array}$ & $\begin{array}{l}0.561 \\
(0.663)\end{array}$ & $\begin{array}{l}0.322 \\
(0.266)\end{array}$ & $\begin{array}{l}0.227 \\
(0.103)\end{array}$ & $\begin{array}{l}0.629 \\
(1.725)\end{array}$ & $\begin{array}{l}0.4350 \\
0.543)\end{array}$ & $\begin{array}{l}0.483 \\
(0.508)\end{array}$ & 0.51 & $\begin{array}{l}0.171 \\
(0.078)\end{array}$ \\
\hline - Capital ratio & $\begin{array}{l}0.057 \\
(0.017)\end{array}$ & $\begin{array}{l}0.056 \\
(0.012)\end{array}$ & $\begin{array}{l}0.058 \\
(0.017)\end{array}$ & $\begin{array}{l}0.050 \\
(0.008)\end{array}$ & $\begin{array}{l}0.052 \\
(0.007)\end{array}$ & $\begin{array}{l}0.060 \\
(0.016)\end{array}$ & $\begin{array}{l}0.061 \\
(0.016)\end{array}$ & $\begin{array}{l}0.058 \\
(0.027)\end{array}$ & $\begin{array}{l}0.067 \\
(0.016)\end{array}$ & $\begin{array}{l}0.052 \\
(0.007)\end{array}$ & $\begin{array}{l}0.056 \\
(0.016)\end{array}$ & $\begin{array}{l}0.0560 \\
(0.014)\end{array}$ & 0.046 & 0.05 & $\begin{array}{l}0.048 \\
(0.011)\end{array}$ \\
\hline \multicolumn{16}{|c|}{ Panel B: County elections } \\
\hline No. of elections & 72 & 5 & 4 & 6 & 5 & 6 & 7 & 5 & 4 & 5 & 5 & 5 & 5 & 5 & 5 \\
\hline Vote share $C D U$ & $\begin{array}{c}39.83 \\
(8.44)\end{array}$ & $\begin{array}{c}36.88 \\
(7.04)\end{array}$ & $\begin{array}{l}42.46 \\
(6.04)\end{array}$ & $\begin{array}{c}33.57 \\
(8.28)\end{array}$ & $\begin{array}{c}22.52 \\
(6.26)\end{array}$ & $\begin{array}{c}29.99 \\
(5.24)\end{array}$ & $\begin{array}{c}36.44 \\
(8.09)\end{array}$ & $\begin{array}{c}35.38 \\
(7.11)\end{array}$ & $\begin{array}{l}42.10 \\
(9.61)\end{array}$ & $\begin{array}{c}29.19 \\
(7.86)\end{array}$ & $\begin{array}{c}42.90 \\
(8.72)\end{array}$ & $\begin{array}{c}40.72 \\
(7.71)\end{array}$ & $\begin{array}{l}41.73 \\
(7.39)\end{array}$ & $\begin{array}{l}41.04 \\
(6.56)\end{array}$ & $\begin{array}{r}36.87 \\
(7.83)\end{array}$ \\
\hline Vote share $S P D$ & $\begin{array}{l}29.63 \\
(10.32)\end{array}$ & $\begin{array}{c}21.07 \\
(5.09)\end{array}$ & $\begin{array}{c}23.40 \\
(8.28)\end{array}$ & $\begin{array}{c}29.03 \\
(5.18)\end{array}$ & $\begin{array}{c}27.94 \\
(7.03)\end{array}$ & $\begin{array}{c}39.35 \\
(6.09)\end{array}$ & $\begin{array}{c}38.03 \\
(5.93)\end{array}$ & $\begin{array}{c}38.58 \\
(7.87)\end{array}$ & $\begin{array}{l}38.08 \\
(8.16)\end{array}$ & $\begin{array}{c}23.17 \\
(5.14)\end{array}$ & $\begin{array}{c}34.22 \\
(8.77)\end{array}$ & $\begin{array}{c}34.353 \\
(8.17)\end{array}$ & $\begin{array}{l}34.83 \\
(5.25)\end{array}$ & $\begin{array}{l}41.94 \\
(8.16)\end{array}$ & $\begin{array}{l}21.36 \\
(6.22)\end{array}$ \\
\hline Vote share swing & $\begin{array}{l}9.58 \\
(2.79)\end{array}$ & $\begin{array}{l}8.22 \\
(2.29)\end{array}$ & $\begin{array}{l}9.00 \\
(2.41)\end{array}$ & $\begin{array}{c}12.56 \\
(0.00)\end{array}$ & $\begin{array}{c}16.57 \\
(2.24)\end{array}$ & $\begin{array}{c}12.88 \\
(0.26)\end{array}$ & $\begin{array}{c}14.39 \\
(0.00)\end{array}$ & $\begin{array}{c}10.24 \\
(1.67)\end{array}$ & $\begin{array}{l}6.31 \\
(2.24)\end{array}$ & $\begin{array}{c}13.18 \\
(2.38)\end{array}$ & $\begin{array}{l}9.58 \\
(1.07)\end{array}$ & $\begin{array}{l}12.18 \\
(1.84)\end{array}$ & $\begin{array}{l}9.05 \\
(1.50)\end{array}$ & $\begin{array}{c}13.56 \\
(1.93)\end{array}$ & $\begin{array}{l}13.18 \\
(2.38)\end{array}$ \\
\hline Party change & $\begin{array}{l}0.127 \\
(0.177)\end{array}$ & $\begin{array}{l}0.059 \\
(0.114)\end{array}$ & $\begin{array}{l}0.066 \\
(0.159)\end{array}$ & $\begin{array}{l}0.200 \\
(0.000)\end{array}$ & $\begin{array}{l}0.521 \\
(0.243)\end{array}$ & $\begin{array}{l}0.127 \\
(0.113)\end{array}$ & $\begin{array}{l}0.417 \\
(0.000)\end{array}$ & $\begin{array}{l}0.243 \\
(0.154)\end{array}$ & $\begin{array}{l}0.088 \\
(0.109)\end{array}$ & $\begin{array}{l}0.375 \\
(0.381)\end{array}$ & $\begin{array}{l}0.114 \\
(0.137)\end{array}$ & $\begin{array}{l}0.1720 \\
(0.172)\end{array}$ & $\begin{array}{l}0.295 \\
(0.165)\end{array}$ & $\begin{array}{l}0.290 \\
(0.201)\end{array}$ & $\begin{array}{l}0.125 \\
(0.276)\end{array}$ \\
\hline \multicolumn{16}{|c|}{ Panel C: County districts } \\
\hline No. of districts & 373 & 44 & 96 & 1 & 18 & 2 & 1 & 26 & 46 & 8 & 52 & 36 & 5 & 15 & 23 \\
\hline Population & 75.248 & 10.745 & 12.510 & 3.443 & 2.493 & 0.662 & 1.774 & 6.062 & 7.911 & 1.651 & 17.873 & 4.0131 & 1.023 & 2.838 & 2.250 \\
\hline Real GDP & $\begin{array}{l}6.648 \\
(8.447)\end{array}$ & $\begin{array}{l}8.381 \\
(5.251)\end{array}$ & $\begin{array}{c}5.954 \\
(11.971)\end{array}$ & $\begin{array}{c}84.448 \\
(3.773)\end{array}$ & $\begin{array}{l}2.619 \\
(0.721)\end{array}$ & $\begin{array}{c}11.049 \\
(8.798)\end{array}$ & $\begin{array}{c}78.662 \\
(2.799)\end{array}$ & $\begin{array}{l}7.852 \\
(8.224)\end{array}$ & $\begin{array}{l}6.060 \\
(8.041)\end{array}$ & $\begin{array}{l}2.682 \\
(1.366)\end{array}$ & $\begin{array}{c}11.049 \\
(7.891)\end{array}$ & $\begin{array}{c}3.28 \\
(2.093)\end{array}$ & $\begin{array}{l}5.651 \\
(3.674)\end{array}$ & $\begin{array}{l}5.185 \\
(2.124)\end{array}$ & $\begin{array}{l}2.058 \\
(1.043)\end{array}$ \\
\hline Unempl. rate & $\begin{array}{l}8.32 \\
(3.39)\end{array}$ & $\begin{array}{l}6.11 \\
(1.83)\end{array}$ & $\begin{array}{l}6.81 \\
(2.56)\end{array}$ & $\begin{array}{c}15.49 \\
(3.80)\end{array}$ & $\begin{array}{c}18.88 \\
(4.38)\end{array}$ & $\begin{array}{c}16.52 \\
(3.53)\end{array}$ & $\begin{array}{c}10.91 \\
(1.54)\end{array}$ & $\begin{array}{l}8.35 \\
(2.73)\end{array}$ & $\begin{array}{l}10.48 \\
(2.82)\end{array}$ & $\begin{array}{c}18.01 \\
(3.21)\end{array}$ & $\begin{array}{c}10.14 \\
(2.79)\end{array}$ & $\begin{array}{l}8.43 \\
(2.71)\end{array}$ & $\begin{array}{c}10.63 \\
(3.01)\end{array}$ & $\begin{array}{l}10.31 \\
(2.94)\end{array}$ & $\begin{array}{c}16.55 \\
(3.72)\end{array}$ \\
\hline
\end{tabular}

Notes: States are abbreviated as follows: $\mathrm{BW}=$ Baden-Württemberg, $\mathrm{BV}=$ Bavaria, $\mathrm{BE}=$ Berlin, $\mathrm{BR}=$ Brandenburg, $\mathrm{BR}=$ Bremen, $\mathrm{HA}=$ Hamburg, HS=Hesse, LS=Lower Saxony, MW=Mecklenburg-Western Pomerania, NW=North Rhine-Westphalia, $\mathrm{RP}=$ Rhineland-Palatinate, $\mathrm{SL}=$ Saarland, $\mathrm{SH}=$ Schleswig-Holstein $\mathrm{TH}=$ Thuringia. Reported are total numbers (for the state level) and means (for the district level) respectively. For the latter, standard deviations are in brackets. Election data refers to county elections of legislative bodies. $C D U$ is the conservative party (for Bavaria, depicted results are for CDU's sister party: CSU) and SPD the social-democratic party of Germany. "Vote share swing" denotes the average swing in vote shares (cumulated over all parties) that results from a given election. "Party change" indicates the share of elections that result in a change of the winning party. State population is measured in million habitants (as of 2010). All monetary values are measured in 1995 EUR billion. 
Figure 1. Time trends in bank lending

Savings bank lending across states

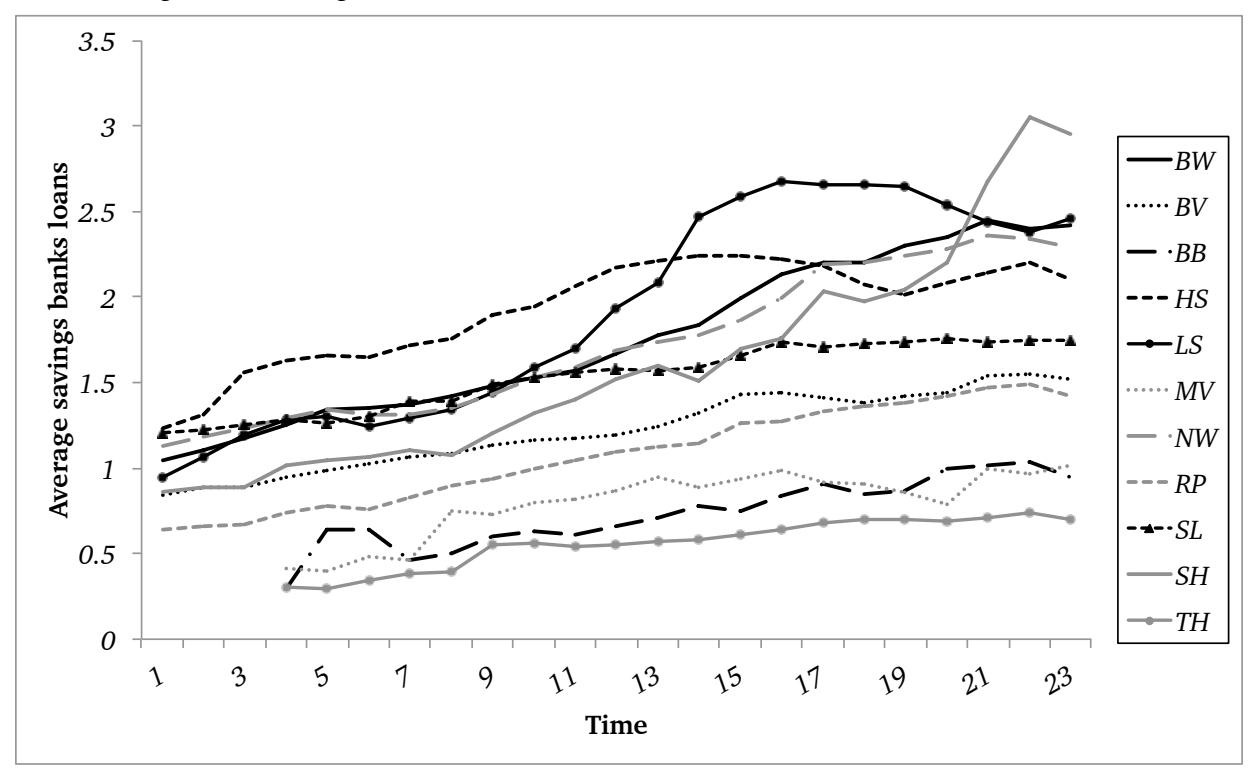

Notes: Depicted are time series from a balanced panel of average savings bank lending for Baden-Württemberg (BW), Bavaria (BV), Brandenburg (BB), Hesse (HS), Lower Saxony (LS), Mecklenburg-Western Pomerania (MW), North Rhine-Westphalia (NW), Rhineland-Palatinate (RP), Saarland (SL), Schleswig-Holstein (SH), and Thuringia (TH). City states (Berlin, Bremen, and Hamburg) are omitted for better readability. Loans are measured in 1995 EUR billion.

rather static political environment. As an illustration, consider that only about $6 \%$ of all county elections in Bavaria and Baden-Württemberg result in a change of the winning party, whereas other states on average experience such changes in power after $16 \%$ of all elections.

Note that these summary statistics are for pooled data and represent an average over time. To better assess the dynamics of German bank lending, figure 1 plots the time series of average savings bank lending, stratified by state. ${ }^{15}$ Clearly, the loan data is subject to an upward trend, which makes it necessary to control for time effects. Overall, savings banks across states appear to be on similar time trends, assuring the validity of the difference-in-difference identification strategy (see Angrist and Pischke, 2009). If anything, the time trends of Hesse, Lower Saxony, and Schleswig-Holstein appear a bit idiosyncratic, which is why results that seem exclusively driven by either of these three states would have to be taken with a grain of salt. On this account, section 7.3 gauges the robustness of results

\footnotetext{
${ }^{15}$ For better readability, trends for the three city-states, Berlin, Bremen, and Hamburg (accounting for a total of six savings banks) are omitted.
} 
Figure 2. Time trends in bank lending Savings bank versus cooperative bank lending

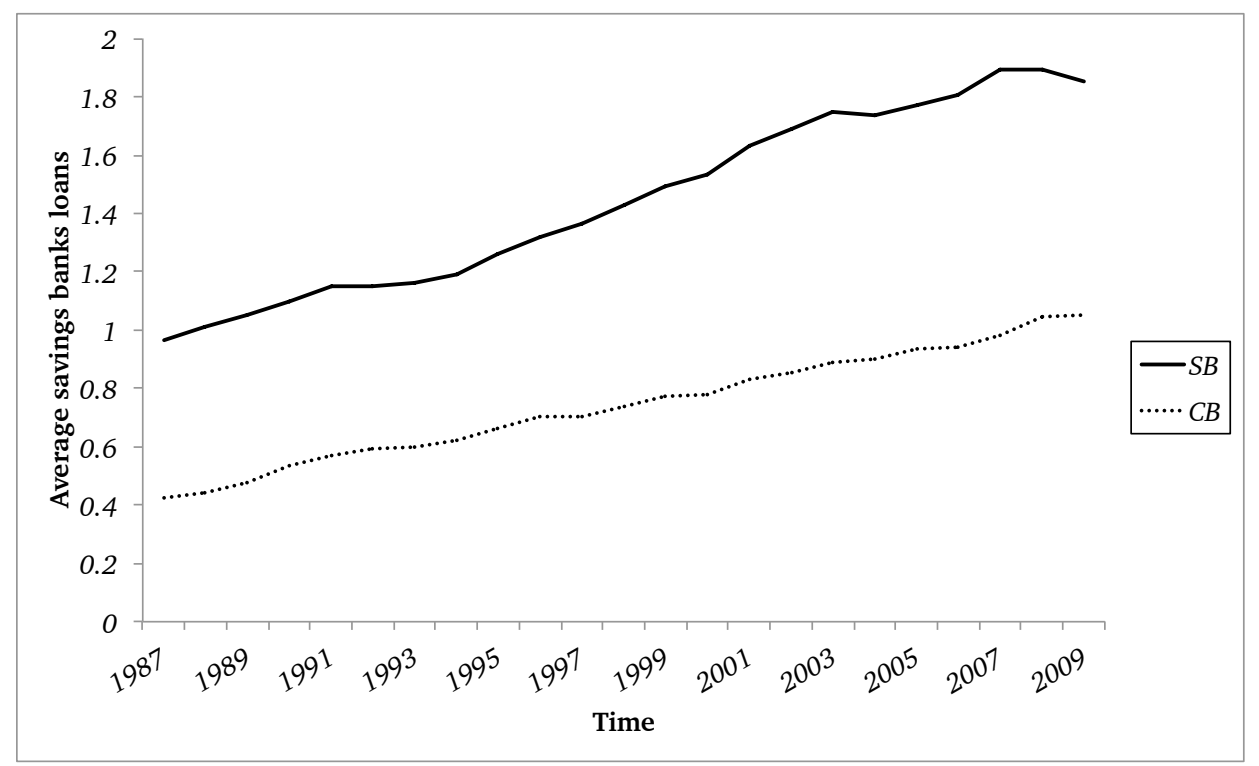

Notes: Depicted are time series from a balanced panel of savings bank (SB) and cooperative bank (CB) lending, averaged over all 14 states in the sample. Loans are measured in 1995 EUR billion.

when these states are dropped from the sample. Finally, figure 2 shows that time trends are also comparable for both bank types (averaged over all states in the sample), which provides further evidence that cooperative banks are indeed a valid control group for savings banks.

\section{Methodology}

Our strategy to identify clean causal effect of elections on savings bank lending, relies on the fact that we should only observe politically motivated lending before election years, only in counties in which elections are held at this point in time, and - importantly - only for politically connected savings banks. Identification is facilitated by a high degree of variation in electoral timing and the existence of a control group of cooperative banks that operate in the same electoral districts as savings banks. Furthermore, given the statutory nature of legislative elections at the county level, for which early elections are de-facto non-existent, we need not worry about any endogeneity in the timing of the key regressor. Econometrically, we conduct difference-in-difference (DD) as well as triple-difference (DDD) estimation embedded in a fixed-effects panel setup. 
Testing prediction 1: Election effect

To test prediction 1 that savings bank lending increases in the run-up to elections, we use the following empirical specification:

$$
Y_{i b s t}=\mathbf{X}_{\mathrm{ibst}}^{\prime} \boldsymbol{\beta}_{\mathbf{1}}+\mathbf{S}_{\mathbf{s}}^{\prime} \gamma_{\mathbf{1}}+\mathbf{T}_{\mathbf{t}}^{\prime} \boldsymbol{\lambda}_{\mathbf{1}}+\mu_{1} B_{b}+\theta_{1} E L E C_{s t}^{C}+\delta_{1} E L E C_{s t}^{C} * B_{b}+\epsilon_{i b s t} .
$$

where $Y_{i b s t}$ is a measure for loans from bank $i$ of bank type $b$ (savings vs. cooperative bank), operating in state $s$ at time $t$. The parameter of interest, $\delta_{1}$, estimates the causal effect of county election seasons - which are indicated by the pre-election dummy variable $E L E C_{s t}^{C}$ - on savings bank lending. To ensure identification of $\delta_{1}$, we control for the following fixed effects and covariates: $\mathbf{S}_{\mathbf{s}}$ denotes a full vector of state effects to control for secular lending differences across states. Similarly, time effects, $\mathbf{T}_{\mathbf{t}}$, are included to capture any national trends or year shocks. In addition, bank-type effects, $B_{b}$, are needed to control for perpetual differences between savings and cooperative banks. $B_{b}$ is defined as a dummy variable that takes on the value of 1 if the individual unit is a savings bank. We interact the pre-election dummy with the bank-type indicator such that $E L E C_{s t}^{C} * B_{b}$ switches on if and only if $Y_{i b s t}$ measures lending activity of a savings bank during an election season. Finally, $\mathbf{X}_{\mathbf{i b s t}}$ is a vector of bank- and district-specific variables that may directly influence the outcome variable. The inclusion of these covariates should considerably improve the predictability of $Y_{i b s t}$, which will in turn reduce the sample variance of the estimates.

Estimation of model 1 by OLS ensures that both cross-sectional and timeseries variation are exploited. The former compares the same banks across time, as each bank will be subject to recurring election "treatments". The latter contrasts different banks at a given time, as county elections dates vary across states. Furthermore, the control group of cooperative banks permits an encompassing representation of counterfactual lending in the absence of elections because politicians have no institutional sway over credit policies of these financial institutions. Consequently, the DD estimate for $\delta_{1}$ captures the difference between election-induced increases in savings bank lending (which is expected to be positive after controlling for time trends) and election-induced increases in cooperative-bank lending (which is expected to be zero after controlling for time trends).

To further illustrate the identification strategy, consider the following example: 
Figure 3. Map of the cities of Ulm and Neu-Ulm

Location of savings banks and cooperative banks

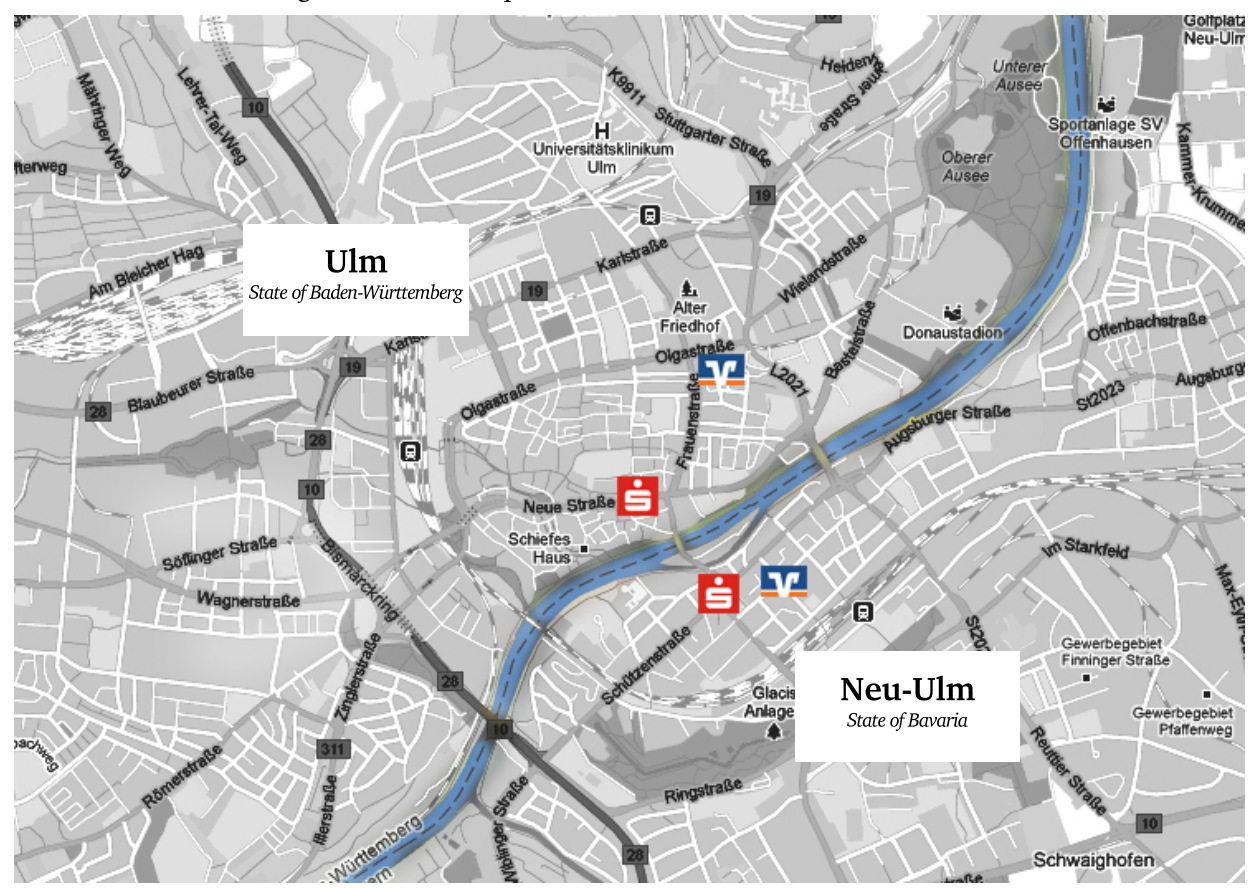

Notes: Depicted is a map of the German cities of Ulm and Neu-Ulm. The red and blue-orange emblems denote the location of savings banks and cooperative banks in these municipalities, respectively. Source: Google maps.

Figure 3 depicts a map of the cities of Ulm (situated in the state of BadenWürttem-berg) and Neu-Ulm (located in the state of Bavaria), which - historically as well as geographically - can be interpreted as one municipality that is arbitrarily divided by the Danube river (highlighted in blue). In our sample, we observe the savings bank Sparkasse Ulm (marked by the red savings bank emblem north-west of the river) over time, which enables us to compare its lending behavior in election years to that in off-election years. Additionally, we can contrast its credit policy with that of Sparkasse Neu-Ulm-Illertissen, a Bavarian savings bank that is literally a stone's throw away (depicted by the red emblem south-east of the river): Since intervals between county elections are different for the two states in question, we are able to exploit information from years during which both cities, neither of the cities, and either one of the two cities face an election. On top of that, we can contrast savings bank loans for any given year with those of politically unconnected cooperative banks Volksbank Ulm-Biberach and Volksbank Neu-Ulm, marked by blue-orange cooperative-bank emblems. Extending this analysis to the 379 counties in our sample, arguably provides us with a sound characterization of what counterfactual lending in the absence of elections would look like. 


\section{Testing prediction 2: Election type}

More evidence for the main hypothesis would be provided if prediction 2 - that only county elections, and not state elections have a systematic impact on savings bank lending - were to be confirmed by the data as well.

Empirical testing of prediction 2 is straightforward, as model 1 can be applied almost verbatim since both, legislative county elections and state elections, vary at the state level. The only difference to the specification used for prediction 1 is that $E L E C_{s t}^{C}$ is replaced with an indicator for state election seasons, $E L E C_{s t}^{S} .{ }^{16}$

$$
Y_{i b s t}=\mathbf{X}_{\mathbf{i b s t}}^{\prime} \boldsymbol{\beta}_{\mathbf{2}}+\mathbf{S}_{\mathbf{s}}^{\prime} \boldsymbol{\gamma}_{\mathbf{2}}+\mathbf{T}_{\mathbf{t}}^{\prime} \boldsymbol{\lambda}_{\mathbf{2}}+\mu_{2} B_{b}+\theta_{2} E L E C_{s t}^{S}+\delta_{2} E L E C_{s t}^{S} * B_{b}+\epsilon_{i b s t} .
$$

\section{Testing prediction 3: Lending cycle}

Another way of solidifying support for the main hypothesis is to look at postelection periods, as the increase in lending should be confined to the immediate election season. Particularly, we expect lending policies to quickly return to their steady-state level once ballots are cast. Prediction 3 can be tested with the following specification to be estimated with OLS:

$$
Y_{i b s t}=\mathbf{X}_{\mathbf{i b s t}}^{\prime} \boldsymbol{\beta}_{\mathbf{3}}+\mathbf{S}_{\mathbf{s}}^{\prime} \boldsymbol{\gamma}_{\mathbf{3}}+\mathbf{T}_{\mathbf{t}}^{\prime} \boldsymbol{\lambda}_{\mathbf{3}}+\mu_{3} B_{b}+\theta_{3} E L E C_{s t-\tau}^{C}+\delta_{3} E L E C_{s t-\tau}^{C} * B_{b}+\epsilon_{i b s t},
$$

To study post-election periods, we separately estimate equation 3 with $\tau=$ $(1,2,3,4)$, such that the dummy variable $E L E C_{s t-\tau}^{C}$ indicates whether there was an election in state $s, \tau$ years ago. We expect the estimate of $\delta_{3}$ to be either zero or, in case of binding credit constraints, negative. To gauge how far in advance lending increases will have to take effect to leave a footprint in the minds of voters, we also examine the year preceding the election year by setting $\tau=-1$. With an average interval between elections of 5 years, the last-mentioned effect should be comparable to that of $\tau=+4$, as it blurs the line between post-election periods of the past and pre-election periods of the next campaign.

\footnotetext{
${ }^{16}$ Note that we refrain from replicating this analysis with federal elections, as their effect would not be identified when year dummies are used to control for time effects: Federal election dates only vary in the time dimension (with the usual interval being 4 years), rendering them indistinguishable from year shocks.
} 
Testing prediction 4: Electoral competition

The test for prediction 4 can be implemented with the following DDD model, estimated with OLS:

$$
\begin{aligned}
Y_{i b s t} & =\mathbf{X}_{\mathrm{ibst}}^{\prime} \boldsymbol{\beta}_{\mathbf{4}}+\mathbf{S}_{\mathbf{s}}^{\prime} \boldsymbol{\gamma}_{\mathbf{4}}+\mathbf{T}_{\mathbf{t}}^{\prime} \boldsymbol{\lambda}_{4}+\mu_{4} B_{b}+\psi_{4} I_{i t}+\theta_{4} E L E C_{s t}^{C}+\ldots \\
& +\phi_{4}^{1} B_{b} * I_{i t}+\phi_{4}^{2} B_{b} * E L E C_{s t}^{C}+\phi_{4}^{3} I_{i t} * E L E C_{s t}^{C}+\ldots \\
& +\delta_{4} E L E C_{s t}^{C} * B_{b} * I_{i t}+\epsilon_{i b s t},
\end{aligned}
$$

where $I_{i t}$ is the respective indicator variable of interest: In case current electoral competition is investigated, $I_{i t}=C_{i t}$ is an indicator for whether the upcoming election is contested. The ruling party's past entrenchment (or alternatively: the lack of local electoral competition in general) is measured with $I_{i t}=E_{i t}$. In line with the predictions in section 3 , the former indicator switches on if the current election is competed, while the latter takes the value of one in case the local political process is generally not contested. To ensure robustness, we present several alternative measures for electoral contestedness and party entrenchment (see section 6). The first line of model 4 contains the usual controls as well as all main fixed effects. Line 2 contains the full set of first-order interactions which are necessary to identify the causal effect of interest, captured by the DDD estimate of $\delta_{4}$ in line 3 (see Gruber, 1994).

\section{Main empirical specification}

All results presented in section 6 are estimates from an unbalanced panel to which we apply the following empirical specification: The dependent variable, $Y_{i b s t}$, is defined as the natural logarithm of loans of bank $i$ as reported in the balance sheet for year $t$, normalized by total assets to account for the size of the respective bank. Note that log-transformation does not drive our results but facilitates interpretation of coefficients - which represent (semi-)elasticities - and accounts for the right-skewedness of our data. The pre-election indicator, $E L E C_{s t}^{C}$, is defined as follows: It takes on the value of 1 if there is an election in either the final two quarters of the same year, or the first two quarters of the following year. ${ }^{17}$ The vector of control variables, $\mathbf{X}_{\mathrm{ibst}}$, includes bank-specific (total assets and capital ratio) and district-specific (population size, real GDP, as well

\footnotetext{
${ }^{17}$ This definition ensures that election-induced lending is reflected in the balance sheet of the actually relevant year: If an election takes place in, say, January, pre-election lending will arguably leave its mark in the balance sheet of the previous year, which is why the latter will switch on
} 
as population and GDP growth rates) time-varying covariates. To account for the possibility that the bank variables are only sequentially exogenous, we use their lagged values instead (see Dinç, 2005). All elements of $\mathbf{X}_{\mathbf{i b s t}}$ are log-transformed. Finally, standard errors are clustered at the bank level (as opposed to the bankyear level) to correct for substantial serial correlation. Note that the results are not driven by these modeling choices. As section 7 demonstrates, the main conclusions are insensitive to estimator choices, assumptions regarding the errorterm structure, varying definitions of key variables, sets of controls, and sample compositions. Notably, results remain intact if the set of covariates is replaced with bank fixed effects and if standard errors are clustered at the district or the state level.

\section{Results}

In a nutshell, all of the testable predictions withstand empirical scrutiny, which strongly corroborates the hypothesis that there is a politically induced lending cycle. Not only do estimated effects have the correct sign, they are also statistically significant at least at the $5 \%$ level, and in many cases even at the $0.1 \%$ level.

Prediction 1: Do savings banks expand lending prior to county elections?

The empirical test of prediction 1 is summarized in column (A) of table 2, which contains OLS estimates of the key parameters from model 1 as well as regression coefficients of control variables. These results suggest that in the run-up to county elections the average savings bank experiences a $2.1 \%$ increase in the stock of lending. This estimate is statistically highly significant at the $0.1 \%$ level. To provide a better sense for the magnitude of the effect, consider that its absolute size amounts to an average of EUR 56.9 million extra stock in lending per bank. Note that this increase is relative to the total stock in bank lending. If we were able to observe the extension of new credit contracts, relative effect sizes would be substantially larger. Providing a back-of-the-envelope calculation and

$E L E C_{s t}^{C}$, whereas $E L E C_{s t}^{C}=0$ for the actual election year. By contrast, if the election is held around year's end, the balance sheet of the preceding year is probably less informative than that of the election year, for which reason the pre-election indicator would then coincide with the year of the election. 
Table 2. Results for predictions 1 and 2

Dependent variable: Log loans normalized by total assets

\begin{tabular}{|c|c|c|c|c|}
\hline \multirow[t]{2}{*}{$\begin{array}{l}\text { Explanatory } \\
\text { variables }\end{array}$} & \multicolumn{4}{|c|}{$\begin{array}{c}\text { OLS regression coefficients } \\
\text { (Robust standard errors in brackets) }\end{array}$} \\
\hline & (A) & (B) & (C) & (D) \\
\hline \multicolumn{5}{|l|}{ Key regressors } \\
\hline$-E L E C_{s t}^{C} * B_{b}$ & $\begin{array}{l}0.021 * * * \\
(0.005)\end{array}$ & - & - & $\begin{array}{l}0.022 * * * \\
(0.005)\end{array}$ \\
\hline$-E L E C_{s t}^{C}$ & $\begin{array}{r}-0.005 \\
(0.004)\end{array}$ & $\begin{array}{l}-0.001 \\
(0.004)\end{array}$ & - & $\begin{array}{r}-0.005 \\
(0.004)\end{array}$ \\
\hline$-E L E C_{s t}^{S} * B_{b}$ & - & - & $\begin{array}{l}0.004 \\
(0.005)\end{array}$ & $\begin{array}{l}0.006 \\
(0.005)\end{array}$ \\
\hline$-E L E C_{s t}^{S}$ & - & - & $\begin{array}{c}-0.004 \\
(0.004)\end{array}$ & $\begin{array}{l}-0.003 \\
(0.004)\end{array}$ \\
\hline \multicolumn{5}{|l|}{ Bank controls } \\
\hline - Total assets & $\begin{array}{c}-0.008 \\
(0.005)\end{array}$ & $\begin{array}{l}-0.007 \\
(0.007)\end{array}$ & $\begin{array}{l}-0.008 \\
(0.005)\end{array}$ & $\begin{array}{l}-0.008 \\
(0.005)\end{array}$ \\
\hline - Capital ratio & $\begin{array}{l}0.112^{*} \\
(0.044)\end{array}$ & $\begin{array}{l}0.176 * * \\
(0.066)\end{array}$ & $\begin{array}{l}0.112 * \\
(0.044)\end{array}$ & $\begin{array}{l}0.112 * \\
(0.044)\end{array}$ \\
\hline \multicolumn{5}{|l|}{ District controls } \\
\hline - Population & $\begin{array}{l}0.002 \\
(0.015)\end{array}$ & $\begin{array}{l}0.016 \\
(0.022)\end{array}$ & $\begin{array}{l}0.002 \\
(0.015)\end{array}$ & $\begin{array}{l}0.002 \\
(0.015)\end{array}$ \\
\hline - Popul. growth & $\begin{array}{l}1.710 * \\
(0.732)\end{array}$ & $\begin{array}{l}2.035 \\
(1.185)\end{array}$ & $\begin{array}{c}1.724 * \\
(0.732)\end{array}$ & $\begin{array}{c}1.708 * \\
(0.732)\end{array}$ \\
\hline - Real GDP & $\begin{array}{l}0.015 \\
(0.013)\end{array}$ & $\begin{array}{c}-0.001 \\
(0.184)\end{array}$ & $\begin{array}{l}0.015 \\
(0.013)\end{array}$ & $\begin{array}{l}0.015 \\
(0.013)\end{array}$ \\
\hline - GDP growth & $\begin{array}{l}0.075 \\
(0.047)\end{array}$ & $\begin{array}{l}0.082 \\
(0.067)\end{array}$ & $\begin{array}{l}0.073 \\
(0.047)\end{array}$ & $\begin{array}{l}0.074 \\
(0.047)\end{array}$ \\
\hline State FE & Yes & Yes & Yes & Yes \\
\hline Time FE & Yes & Yes & Yes & Yes \\
\hline Bank type FE & Yes & No & Yes & Yes \\
\hline Banks in sample & All & Coop & All & All \\
\hline Election & County & County & State & Both \\
\hline $\mathrm{N}$ & 11,511 & 6,300 & 11,511 & 11,511 \\
\hline $\mathrm{R}^{2}$ & 0.235 & 0.149 & 0.234 & 0.235 \\
\hline
\end{tabular}

Notes: Results are for the main empirical specification (see section 5). Key regressors are $E L E C_{s t}^{C} * B_{b}, E L E C_{s t}^{C}$, and $E L E C_{s t}^{S} * B_{b}$, respectively. The indexes $C$ and $S$ denote county and state elections, respectively. Coop stands for cooperative banks. Standard errors are clustered at the bank level and are stated in brackets. $*$, **, and *** indicate statistical significance at the $5 \%$, the $1 \%$, and the $0.1 \%$ level, respectively.

assuming an average loan tenure of 3-4 years, this estimate would translate into a 6-8\% effect on newly extended credit.

Besides this causal effect of interest, the bank's capital ratio and population growth in the electoral district are additional covariates with a statistically sig- 
nificant impact on lending. All other variables, albeit not exerting significant influence, enter the model with intuitive signs.

As the second entry in column (A) indicates, the lending behavior of cooperative banks appears to be unaffected by municipal elections - a result that is corroborated in column (B), which contains results from estimating the effect of elections in a sample that only contains cooperative banks. This finding confirms that the hike in pre-election lending is unlikely to be demand-side driven, since one would expect any macro-economic factors to influence the entire banking sector and not only politically controlled savings banks.

\section{Prediction 2: Does lending react to state elections?}

Now we turn to the second prediction that credit policy should react only to county elections. A look at column (C) of table 2 suggests that this seems to indeed be the case. Depicted is the estimate for the causal effect of state elections on savings bank lending. In line with our premise, there is no evidence that lending reacts in any systematic way to elections at higher government levels. This result is confirmed when jointly regressing on both election types (see column (D)). As was the case with the non-effect for cooperative banks, these findings lend additional support to the assertion that we are not simply measuring the consequences of spurred credit demand in response to political business cycle policies, since these should arguably be in place before state election as well.

Prediction 3: What happens to lending before and after election seasons?

Prediction 3 suggests that the increase in lending should be limited to pre-election periods and quickly disappear, or even become negative, once the election was held. We test this hypothesis by estimating the effect of county elections on savings bank lending in the year preceding and the four years following that election. Results are displayed in table 3, with each column representing a separate regression for which $\tau$ is accordingly varied in model 3 . The effect for the year preceding the election year is depicted in column (A), column (B) has results for the election year (corresponding to those in column (A) of table 2), and postelection years are tackled in columns (C) to (F). Recall that, since the average interval between elections amounts to 5 years, results for $\tau=+4$ should be roughly in line with those for $\tau=-1$, as they mark both, the ending of an old and the beginning of a new electoral cycle. 
Table 3. Results for prediction 3

Dependent variable: Log loans normalized by total assets

\begin{tabular}{lcccccc}
\hline \multirow{2}{*}{$\begin{array}{l}\text { Explanatory } \\
\text { variables }\end{array}$} & \multicolumn{7}{c}{ OLS regression coefficients } \\
& \multicolumn{7}{c}{ (Robust standard errors in brackets) } \\
\cline { 2 - 7 } & Key regressors & $(\mathrm{B})$ & $(\mathrm{C})$ & $(\mathrm{D})$ & $(\mathrm{E})$ & $(\mathrm{F})$ \\
$\quad-E L E C_{\text {st }-\tau}^{C} * B_{b}$ & $0.011^{*}$ & $0.021^{* * *}$ & 0.001 & -0.009 & $-0.009^{*}$ & 0.012 \\
& $(0.005)$ & $(0.005)$ & $(0.005)$ & $(0.006)$ & $(0.005)$ & $(0.005)$ \\
$-E L E C_{\text {st }-\tau}^{C}$ & -0.003 & -0.005 & -0.007 & 0.004 & 0.001 & -0.003 \\
& $(0.004)$ & $(0.004)$ & $(0.004)$ & $(0.005)$ & $(0.004)$ & $(0.004)$ \\
Bank controls & Yes & Yes & Yes & Yes & Yes & Yes \\
District controls & Yes & Yes & Yes & Yes & Yes & Yes \\
State FE & Yes & Yes & Yes & Yes & Yes & Yes \\
Time FE & Yes & Yes & Yes & Yes & Yes & Yes \\
Bank type FE & Yes & Yes & Yes & Yes & Yes & Yes \\
\hline Year relative to election & $\tau=-1$ & $\tau=0$ & $\tau=+1$ & $\tau=+2$ & $\tau=+3$ & $\tau=+4$ \\
\hline $\mathrm{N}$ & 11,511 & 11,511 & 11,511 & 11,511 & 11,511 & 11,511 \\
$\mathrm{R}^{2}$ & 0.245 & 0.235 & 0.235 & 0.235 & 0.235 & 0.235 \\
\hline
\end{tabular}

Notes: Results are for the main empirical specification (see section 5 ). The key regressor is $E L E C_{\text {st }-\tau}^{C} * B_{b}$ for varying $\tau$. $\tau=0$ indicates an election year, $\tau<0$ indicates pre-election years, and $\tau>0$ indicates post-election years. The index $C$ denotes county elections. Standard errors are clustered at the bank level and are stated in brackets. *, **, and **** indicate statistical significance at the $5 \%$, the $1 \%$, and the $0.1 \%$ level, respectively.

As is evident from table 2, a slight but statistically significant (at the 5\% level) increase is already measurable in the year preceding the actual election, indicating an early start of politically induced excess lending. As expected, the effect dissipates directly after the election year, returning to its steady state level. Three years after the election, the election effect dips into significantly negative territory (at the $5 \%$ level). We take this as evidence for (overly) prudent lending policies after elections, consistent with a binding credit constraint that banks face to make up for the excessive pre-election lending. In the fourth year following an election, lending spikes upwards once again to initiate a new cycle. Note that no such cycle is present for cooperative banks, as no estimate in the second row of table 2 is significantly different from zero, suggesting a flat temporal pattern for these banks.

To provide a visual representation of the electoral lending cycle for savings banks, we plot the effects, county elections have on lending in the five years surrounding said election, into figure 4 . The solid line depicts the same point estimates as those in the first row of table 2. The dotted lines indicate 95\% confidence intervals. 
Figure 4. Results for prediction 3

The lending cycle for municipal elections

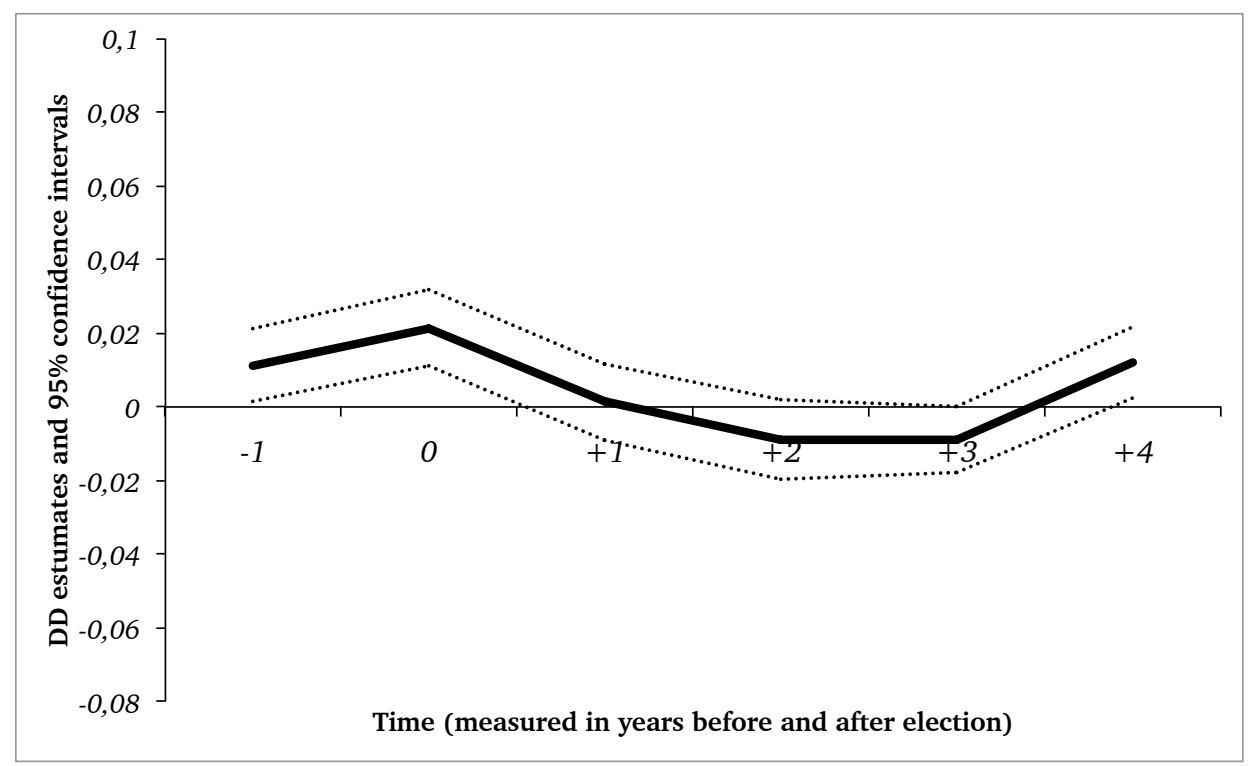

Notes: Results are for the main empirical specification (see section 5). The solid line depicts DD estimates of $\delta_{3}$ coming from model 3. Dottet lines indicate $95 \%$ confidence intervals. Time is measured on the abscissa.

Note that the resulting picture provides, once more, evidence for the political nature of the increase in loan extensions and refutes a more subtle alternative demand-side explanation that customers might correctly anticipate that it will be easier to be granted pre-election loans and therefore pull forward their credit applications from the post- to the election season. If the latter argument had any merit, there should be a marked dip in credit extension in the immediate post-election year, which is, however, not the case.

Prediction 4: What is the role of electoral competition?

Prediction 4 suggests that electoral competition has two separate effects. For one, the increase in lending may depend on the ability to manipulate the bank's policies and hence will be more pronounced, the stronger the general (or historical) entrenchment - represented by $E_{i t}$ - of the incumbent party. This hypothesis is under consideration in column (A) of table 4. To measure the degree of entrenchment, we define an indicator variable E1, that switches on if the electoral district, the bank operates in, experiences relatively few changes in party power. ${ }^{18}$ As col-

\footnotetext{
${ }^{18}$ To construct this measure, we create a normalized index that counts the number of times the strongest party has changed within a district. E1 indicates whether the electoral district under
} 
Table 4. Results for prediction 4

Dependent variable: Log loans normalized by total assets

\begin{tabular}{|c|c|c|c|}
\hline \multirow[t]{2}{*}{$\begin{array}{l}\text { Explanatory } \\
\text { variables }\end{array}$} & \multicolumn{3}{|c|}{$\begin{array}{l}\text { OLS regression coefficients } \\
\text { (Robust standard errors in brackets) }\end{array}$} \\
\hline & (A) & (B) & (C) \\
\hline \multicolumn{4}{|l|}{ DDD Interaction } \\
\hline$-E L E C_{s t}^{C} * B_{b} * E_{i t}$ & $\begin{array}{l}0.019 \\
(0.012)\end{array}$ & - & $\begin{array}{c}0.028 * * \\
(0.011)\end{array}$ \\
\hline$-E L E C_{s t}^{C} * B_{b} * C_{i t}$ & - & $\begin{array}{l}0.017 \\
(0.011)\end{array}$ & $\begin{array}{c}0.028 * \\
(0.012)\end{array}$ \\
\hline \multicolumn{4}{|l|}{ DD Main effect } \\
\hline$-E L E C_{s t}^{C} * B_{b}$ & $\begin{array}{l}0.006 \\
(0.009)\end{array}$ & $\begin{array}{l}0.010 \\
(0.007)\end{array}$ & $\begin{array}{l}-0.011 \\
(0.011)\end{array}$ \\
\hline Bank controls & Yes & Yes & Yes \\
\hline District controls & Yes & Yes & Yes \\
\hline State FE & Yes & Yes & Yes \\
\hline Time FE & Yes & Yes & Yes \\
\hline Bank type FE & Yes & Yes & Yes \\
\hline First-order interactions & Yes & Yes & Yes \\
\hline Measure for $E_{i t}$ & E1 & - & E1 \\
\hline Measure for $C_{i t}$ & - & C1 & $\mathrm{C} 1$ \\
\hline $\mathrm{N}$ & 12,679 & 12,660 & 12,660 \\
\hline $\mathrm{R}^{2}$ & 0.227 & 0.227 & 0.227 \\
\hline
\end{tabular}

Notes: Results are for the main empirical specification (see section 5). $E_{i t}$ indicates whether political entrenchment is generally high in the district, bank $i$ operates in. $C_{i t}$ measures the contestedness of the current election. E1=Indicator for low incumbent party turnover; $\mathrm{C} 1=$ Indicator for winner's vote share $<40 \%$ or margin of victory $<7 \%$. Standard errors are clustered at the bank level and are stated in brackets. *,**, and $* * *$ indicate statistical significance at the $5 \%$, the $1 \%$, and the $0.1 \%$ level, respectively.

umn (A) of table 4 shows, there is some evidence that stability of incumbency may in fact be a precondition for electoral cycles in lending: Only savings banks in politically stable areas increase lending by $1.9 \%$ in the run-up to elections, even though the estimate is only significant at the $10 \%$ level. This election effect is not present in areas that see more frequent changes in power, as indicated by the DD main effect being insignificantly different from zero.

consideration ranks in the bottom quartile of the distribution of said index. Note that a change in relative party strength may not necessarily translate into a change in power, as the party with the plurality of votes may fail to reach an outright majority, in which case it may have to accept opposition status if the other parties agree to form a coalition government. This notwithstanding, E1 should provide a reasonable approximation to the general stability of incumbency, we are ultimately interested in. 
Table 5. Results for prediction 4

Dependent variable: Log loans normalized by total assets

\begin{tabular}{|c|c|c|c|c|c|c|}
\hline \multirow[t]{2}{*}{$\begin{array}{l}\text { Explanatory } \\
\text { variables }\end{array}$} & \multicolumn{6}{|c|}{$\begin{array}{l}\text { OLS regression coefficients } \\
\text { (Robust standard errors in brackets) }\end{array}$} \\
\hline & (A) & (B) & (C) & (D) & (E) & (F) \\
\hline \multicolumn{7}{|l|}{ DDD Interaction } \\
\hline$-E L E C_{s t}^{C} * B_{b} * E_{i t}$ & $\begin{array}{l}0.027^{*} \\
(0.011)\end{array}$ & $\begin{array}{l}0.024 * \\
(0.011)\end{array}$ & $\begin{array}{l}0.018 \\
(0.011)\end{array}$ & $\begin{array}{c}0.031 * * \\
(0.012)\end{array}$ & $\begin{array}{l}0.028^{*} \\
(0.012)\end{array}$ & $\begin{array}{r}0.026^{*} \\
(0.011)\end{array}$ \\
\hline$-E L E C_{s t}^{C} * B_{b} * C_{i t}$ & $\begin{array}{c}0.025^{*} \\
(0.012)\end{array}$ & $\begin{array}{l}0.022 \\
(0.012)\end{array}$ & $\begin{array}{l}0.025 \\
(0.016)\end{array}$ & $\begin{array}{l}0.028^{*} \\
(0.012)\end{array}$ & $\begin{array}{c}0.025^{*} \\
(0.013)\end{array}$ & $\begin{array}{l}0.024 \\
(0.012)\end{array}$ \\
\hline \multicolumn{7}{|l|}{ DD Main effect } \\
\hline$-E L E C_{s t}^{C} * B_{b}$ & $\begin{array}{l}-0.009 \\
(0.010)\end{array}$ & $\begin{array}{l}-0.006 \\
(0.010)\end{array}$ & $\begin{array}{l}0.002 \\
(0.009)\end{array}$ & $\begin{array}{l}-0.003 \\
(0.009)\end{array}$ & $\begin{array}{l}-0.001 \\
(0.009)\end{array}$ & $\begin{array}{l}0.001 \\
(0.008)\end{array}$ \\
\hline Bank controls & Yes & Yes & Yes & Yes & Yes & Yes \\
\hline District controls & Yes & Yes & Yes & Yes & Yes & Yes \\
\hline State FE & Yes & Yes & Yes & Yes & Yes & Yes \\
\hline Time FE & Yes & Yes & Yes & Yes & Yes & Yes \\
\hline Bank type FE & Yes & Yes & Yes & Yes & Yes & Yes \\
\hline First-order interactions & Yes & Yes & Yes & Yes & Yes & Yes \\
\hline Measure for $E_{i t}$ & E1 & E1 & E1 & E2 & E2 & E2 \\
\hline Measure for $C_{i t}$ & $\mathrm{C} 2$ & $\mathrm{C} 3$ & $\mathrm{C} 4$ & $\mathrm{C} 1$ & $\mathrm{C} 2$ & $\mathrm{C} 3$ \\
\hline $\mathrm{N}$ & 12,660 & 12,660 & 12,660 & 12,660 & 12,660 & 12,660 \\
\hline $\mathrm{R}^{2}$ & 0.228 & 0.228 & 0.228 & 0.228 & 0.229 & 0.229 \\
\hline
\end{tabular}

Notes: Results are for the main empirical specification (see section 5). $E_{i t}$ indicates whether political entrenchment is generally high in the district, bank $i$ operates in. $C_{i t}$ measures the contestedness of the current election. E1=Indicator for low incumbent party turnover; E2=Indicator for low contestedness of preceding election; $\mathrm{C} 1=$ Indicator for winner's vote share $<40 \%$ or margin of victory $<7 \%$; $2=$ Indicator for winner's vote share $<37 \%$ or margin of victory $<5 \%$; C $3=$ Indicator for high index of contestedness; $\mathrm{C} 4=$ Indicator for high index of change in winning margin. Standard errors are clustered at the bank level and are stated in brackets. *,**, and *** indicate statistical significance at the $5 \%$, the $1 \%$, and the $0.1 \%$ level, respectively.

The converse effect of current electoral competition, which may increase incentives to induce a lending cycle, is under study in the second column of table 4. Since pre-election polling is generally unavailable for county elections, we have to rely on an ex-post measure when assessing the contestedness - denoted by $C_{i t}$ - of the electoral campaign: the actual election outcome. Though there is an obvious endogeneity issue, we are confident that, given rational expectations and a reasonable feeling of local politicians for the mood of their electorate, the closeness of the final result should provide a reasonable proxy for the perceived closeness of the contest itself. Moreover, below we document that the results are robust to alternative measures of current contestedness. The measure used in the main empirical specification takes on the value of 1 if the winner's final vote 
share is either below $40 \%$ or if the margin of victory is less than $5 \%$. According to estimates in column (B), there is some evidence of current electoral competition exerting systematic influence on the strength of the election effect, which is estimated to be $1.7 \%$ even though statistical significance is only at the $15 \%$ level.

Yet, given that our measure of present contestedness may in part capture the diametric effect of general entrenchment as well, we refine the empirical specification by jointly controlling for both dimensions of electoral competition. Results are displayed in column (C) of table 4. They provide clear evidence that - given overall entrenchment in the district - lending cycles are more likely if the upcoming election promises to be close. According to the point estimates, savings banks in districts that fall into this category, increase their lending by $2.8 \%$ relative to a situation with little competition. Notably, the earlier result that entrenchment can be viewed as a precondition for politically induced lending, is soundly reconfirmed, as statistically significant election effects appear to be exclusively present in districts with high degrees of incumbent entrenchment.

This pattern is corroborated when alternative measures for electoral competition are used. Table 5 contains results for several combinations of various contestedness (C) and entrenchment (E) measures: $\mathrm{C} 1$ and $\mathrm{E} 1$ are defined as above. $\mathrm{C} 2$ is a dummy variable that indicates elections where the winning party accrued less than $37 \%$ of the vote or held a lower than $5 \%$ advantage over the runner-up. ${ }^{19} \mathrm{C} 3$ is a bottom-quartile indicator for a normalized index that measures both, the absolute vote share of the winning party, as well as its margin of victory. C4 indicates an election in the bottom quartile of a normalized index that ranks all observations in our sample by the change in victory margins between elections, i.e., C4 captures whether there are dramatic changes between elections. E2, which measures the closeness of the preceding election to gauge the degree of incumbency power during the current term, is defined as the lagged value of $\mathrm{C} 3$.

To visualize the role of electoral competition, we stratify our sample by political entrenchment and contestedness and concentrate on two polar cases. Particularly, we first apply model 3 to a subsample that consists of districts that

\footnotetext{
${ }^{19}$ Note that for the definition of close elections we have experimented with different cut-off values between the interval of $35 \%$ to $45 \%$ (for the vote share) and $4 \%$ to $8 \%$ (for the margin of victory), which all yielded similar results.
} 
Figure 5. Results for prediction 4

The lending cycle for municipal elections (High entrenchment and high competition)

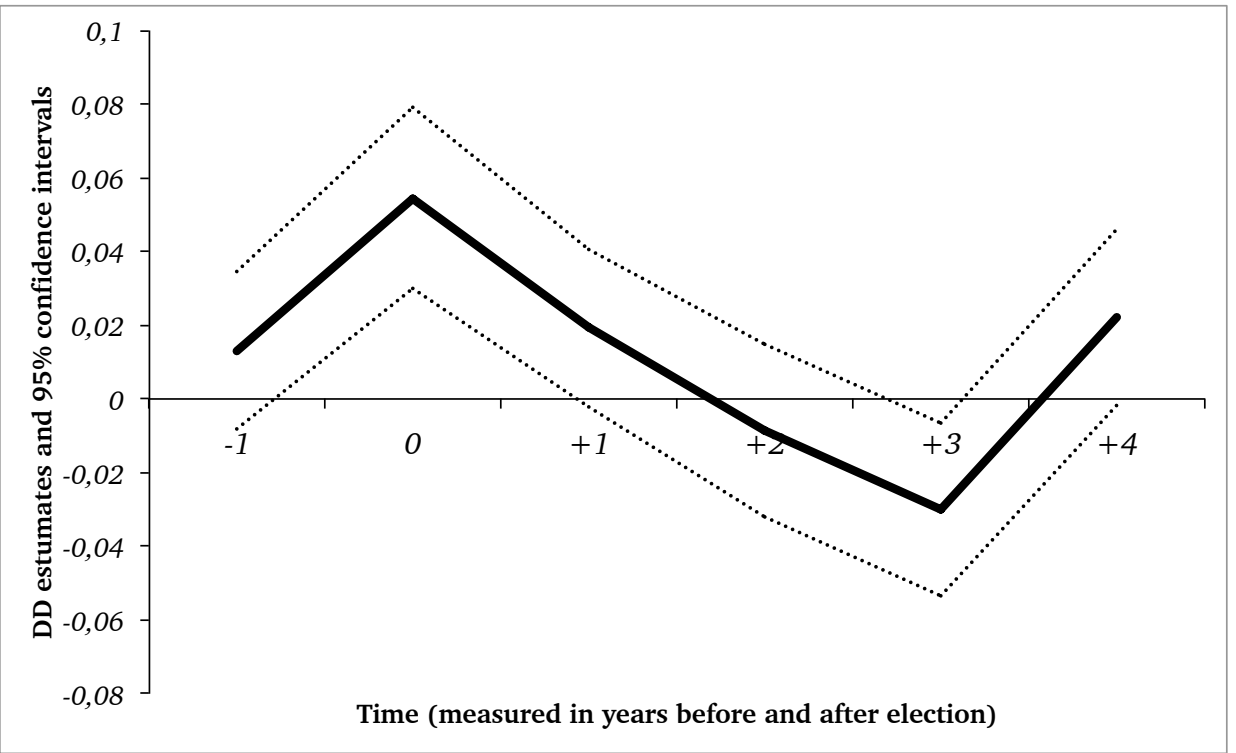

Notes: Results are for the main empirical specification (see section 5). The solid line depicts DD estimates of $\delta_{3}$ coming from model 3. Dottet lines indicate $95 \%$ confidence intervals. Time is measured on the abscissa. Entrenchment is measured by E1 and contestedness is measured by C3.

Figure 6. Results for prediction 4

The lending cycle for municipal elections (Low entrenchment and low competition)

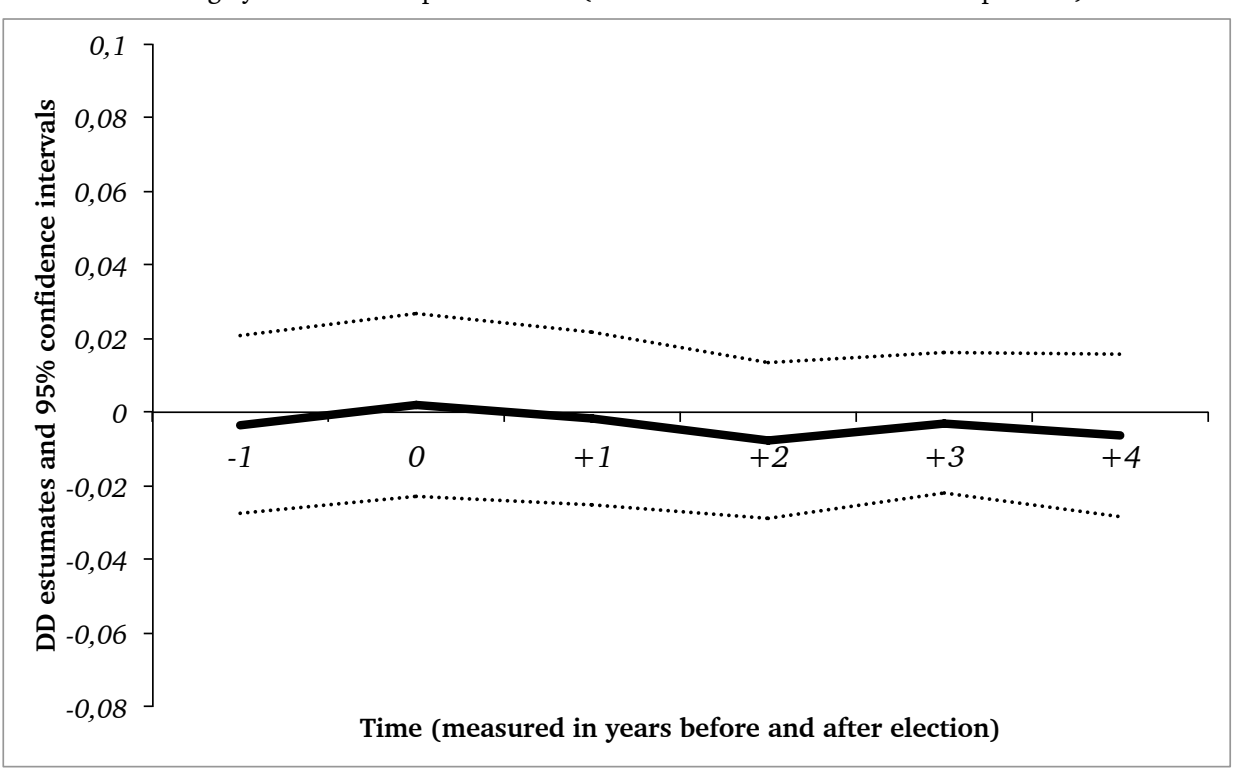

Notes: Results are for the main empirical specification (see section 5). The solid line depicts DD estimates of $\delta_{3}$ coming from model 3. Dottet lines indicate $95 \%$ confidence intervals. Time is measured on the abscissa. Entrenchment is measured by E1 and contestedness is measured by C3. 
are generally characterized by high levels of entrenchment but that face a closer than usual current election. We then fit the same model with data from counties with low levels of entrenchment but low levels of current competition. ${ }^{20}$

The lending cycle for the strata of highly entrenched but currently highly contested areas is depicted in figure 5. As is evident from the graph, the pattern reaffirms all conclusions drawn from the entire sample. However, effect sizes are roughly magnified by a factor of 2 to 3 , indicating that politically induced lending is much more common when politicians have both the ability and the incentive to influence savings bank decisions. In contrast to this, evidence from figure 6, which depicts the lending dynamics of savings banks in counties with low levels of entrenchment but low levels of current competition, suggests that bank activities appear unaffected by the timing of elections. In fact, estimated election effects closely oscillate around zero throughout both pre- and post-election periods. The same holds true for the election season itself, suggesting that the "right" kind of political climate is able to keep local politicians in check.

\section{Robustness}

As mentioned above, results presented in section 6 are based on the main empirical specification being applied to an unbalanced sample that makes use of the maximum information available. To ensure that conclusions are not driven by these choices, we perform a number of robustness checks that demonstrate the immunity of the electoral effect on savings bank lending to varying estimator choices, assumptions regarding the error-term structure, definitions of key variables, sets of controls, and sample compositions.

\subsection{Alternative estimators and modes of statistical inference}

The first robustness analysis we present assesses the stability of results to varying modes of statistical inference. The growing literature on cluster-robust inference (see Bertrand et al., 2004; Angrist and Pischke, 2009; and Cameron and Miller, 2010 for an overview) highlights the importance of accounting for potential serial correlation and regional clustering in panel data. Both phenomena implicate

\footnotetext{
${ }^{20}$ To achieve this, we use the same quartile indicators as before. The resulting strata are of comparable size, containing roughly 2,000 bank-year observation each.
} 
Table 6. Alternative modes of statistical inference

Dependent variable: Log loans normalized by total assets

\begin{tabular}{|c|c|c|c|c|c|c|}
\hline \multirow[t]{2}{*}{$\begin{array}{l}\text { Explanatory } \\
\text { variables }\end{array}$} & \multicolumn{6}{|c|}{$\begin{array}{l}\text { Regression coefficients } \\
\text { (Robust standard errors in brac }\end{array}$} \\
\hline & (A) & (B) & (C) & (D) & (E) & (F) \\
\hline \multicolumn{7}{|l|}{ Key regressors } \\
\hline$-E L E C_{s t}^{C} * B_{b}$ & $\begin{array}{l}0.021 * * * \\
(0.005)\end{array}$ & $\begin{array}{l}0.018 * * * \\
(0.005)\end{array}$ & $\begin{array}{l}0.014 * \\
(0.005)\end{array}$ & $\begin{array}{c}0.015 * * \\
(0.005)\end{array}$ & $\begin{array}{l}0.021 * * * * \\
\quad(0.005)\end{array}$ & $\begin{array}{c}0.021 * \\
(0.008)\end{array}$ \\
\hline - $E L E C_{s t}^{C}$ & $\begin{array}{r}-0.005 \\
(0.004)\end{array}$ & $\begin{array}{c}-0.004 \\
(0.003)\end{array}$ & $\begin{array}{r}-0.001 \\
(0.003)\end{array}$ & $\begin{array}{c}-0.002 \\
(0.004)\end{array}$ & $\begin{array}{r}-0.005 \\
(0.004)\end{array}$ & $\begin{array}{l}-0.005 \\
(0.006)\end{array}$ \\
\hline Bank controls & Yes & Yes & Yes & - & Yes & Yes \\
\hline District controls & Yes & Yes & Yes & Yes & Yes & Yes \\
\hline State FE & Yes & Yes & n.a. & n.a. & Yes & Yes \\
\hline Time FE & Yes & Yes & Yes & Yes & Yes & Yes \\
\hline Bank type FE & Yes & Yes & n.a. & n.a. & Yes & Yes \\
\hline Estimator & OLS & $\mathrm{RE}$ & $\mathrm{FE}$ & $\mathrm{FE}$ & OLS & OLS \\
\hline Cluster & Bank & Bank & Bank & Bank & District & State \\
\hline $\mathrm{N}$ & 11,511 & 11,511 & 11,511 & 11,511 & 11,511 & 11,511 \\
\hline $\mathrm{R}^{2}$ & 0.235 & 0.219 & 0.010 & 0.010 & 0.235 & 0.235 \\
\hline
\end{tabular}

Notes: Abbreviations are as follows: OLS=Ordinary Least Square; RE=Random Effects; FE=Fixed Effects (Within estimator). "Cluster" indicates whether standard errors are clustered on the bank, district, or state level. "n.a." denotes that time-constant variables are omitted. Standard errors are stated in brackets. *, **, and $* * *$ indicate statistical significance at the $5 \%$, the $1 \%$, and the $0.1 \%$ level, respectively.

a violation of one of the main assumptions traditionally imposed when working with cross-sectional data: the independence of observations. While OLS will still be consistent, precision is likely overestimated if these issues are ignored.

\section{Serial correlation}

Serially correlated errors, $\epsilon_{i s t}$, are a typical problem of panel data applications. Formally, $\operatorname{Cor}\left(\epsilon_{i s t}, \epsilon_{i s u}\right)=\rho_{\epsilon} \neq 0$, for $t \neq u$, where $\rho_{\epsilon}$ denotes the intraclass correlation of the error. That is, the individual (here: bank $i$ ) is thought of as a cluster whose observations over time are not independent of one another. A rough estimate of $\rho_{\epsilon}$ - the average autocorrelation over 5 lags of OLS residuals coming from model 1 - equals 0.412 and suggests that our data is indeed subject to substantial serial correlation. For this reason, and in line with Bertrand et al. (2004), Khwaja and Mian (2005), and Cameron and Trivedi (2010), the main empirical specification already corrects for serial correlation by clustering standard errors at the bank level instead of the bank-year level. 
An alternative way of dealing with autocorrelated errors consists of estimating model 1 with a random-effects (RE) specification (see Cameron and Trivedi, 2010). The individual-effects model provides the following rationale for serial correlation: If the error $\epsilon_{i s t}=\alpha_{i}+r_{i s t}$, then the presence of a bank-specific effect, $\alpha_{i}$, induces correlation over time, even if the idiosyncratic component, $r_{i s t}$, is iid. If these assumption on the error structure are correct and as long as $\alpha_{i}$ is truly random, RE is more efficient than OLS, which is why we present results for regression 1, fitted by FGLS in column (B) of table 6. When compared to the baseline specification in column (A), the estimated election effect is only slightly changed by this alternative approach of correcting for serial correlation. The estimated standard deviation of the individual effect, $\hat{\sigma}_{\alpha}$, equals 0.114 and is roughly as large as that of the idiosyncratic error, $\hat{\sigma}_{r}=0.110$. Furthermore, intraclass correlation is estimated to equal 0.427 , which is in line with the ad-hoc estimate, mentioned above.

Of course, the RE estimator is only consistent if $\alpha_{i}$ is uncorrelated with regressors. If we wish to relax this assumption, the individual effect needs to be eliminated with a fixed-effects (FE) specification that only relies on variation over time. Even though we are not particularly worried about correlated effects, results for model 1 when fitted by a within estimator are presented in column (C) of table 6. While the election effect appears to be somewhat smaller than before (amounting to 1.4\%), it is still precisely estimated. We take this as encouraging evidence that the results survive, even when identification is based on within-variation alone. Similar results are achieved when replacing all bankspecific covariates with a simple bank fixed effect (column (D)).

\section{Regional clustering}

If data has a group structure, independence may not only be violated for observations of one individual bank over time, but also across banks that are part of the same regional cluster. In this case, $\epsilon_{i s t}$ will contain some variation that is likely to be common to banks in the same geographical area and year, for instance, a regional business cycle. An obvious solution to this problem is to correct standard errors for clustering at the geographical level, these region-year shocks are most likely to occur.

In the present context, there are two candidates for such regional clusters: the municipal district (which typically contains one savings bank and one to 
four cooperative banks) and the state. While clustering standard errors at the district level is straightforward, this methodological fix usually poses problems for the state level, since robust inference requires a large-enough number of clusters in order to avoid erroneously large standard errors. Even though the literature suggests a minimum number of around 40 to 50 groups to be on the safe side, (see Angrist and Pischke, 2009 and Cameron and Miller, 2010), the effect even remains statistically significant with just 14 states. On this account, results in columns (E) and (F) of table 6 suggest that in the present context regional clustering is not much reason for concern.

\subsection{Alternative choices of variables}

\section{Alternative dependent variables}

We continue by gauging the robustness of that election effect to the choice of the dependent variable. Again, results for the benchmark specification are repeated in column (A) of table 7. Column (B) shows that results are not driven by the decision to normalize log loans by the bank's total assets, as the estimates for the variables of interest do not change if log loans are used instead. In fact, the only change worth mentioning is that the coefficient for total assets (not reported in the table) sharply increases to a very precisely estimated 0.992 , leaving barely any variation in the data unexplained, as is evidenced by $\mathrm{R}^{2}$ exceeding 0.978 . Note that this is not an indication for overfitting. Much rather, this tight connection is not surprising since German financial regulation mandates that a bank's lending position be backed by equivalent net equity. This quasi-mechanical relationship between these variables is yet another reason we opted for normalized dependent variables in the main specification.

In a second deviation from the main empirical model, we re-estimate equation 1 without log-transforming the data. Results in column (C) and (D) show that, while estimated effect sizes appear to slightly decrease, the main conclusions remain nevertheless intact. Note that column (D) provides the aforementioned average size of the election effect in absolute terms, which is estimated to amount to roughly EUR 56.9 million per bank. 
Table 7. Alternative dependent variables

Dependent variables: See table notes

\begin{tabular}{lcccc}
\hline \multirow{2}{*}{$\begin{array}{l}\text { Explanatory } \\
\text { variables }\end{array}$} & \multicolumn{5}{c}{ OLS regression coefficients } \\
& (Robust standard errors in brackets) \\
\cline { 2 - 5 } & (A) & (B) & (C) & (D) \\
\hline Key regressors & & & & \\
$-E L E C_{s t}^{C} * B_{b}$ & $0.021^{* * *}$ & $0.021^{* * *}$ & $0.016^{* * *}$ & 56.862 \\
& $(0.005)$ & $(0.005)$ & $(0.005)$ & $(32.496)$ \\
$-E L E C_{s t}^{C}$ & -0.005 & -0.005 & -0.003 & -1.042 \\
& $(0.004)$ & $(0.004)$ & $(0.003)$ & $(7.125)$ \\
Bank controls & Yes & Yes & Yes & Yes \\
District controls & Yes & Yes & Yes & Yes \\
State FE & Yes & Yes & Yes & Yes \\
Time FE & Yes & Yes & Yes & Yes \\
Bank type FE & Yes & Yes & Yes & Yes \\
\hline Log-transformed & Yes & Yes & - & - \\
Normalized by total assets & Yes & - & Yes & - \\
\hline $\mathrm{N}$ & 11,511 & 11,511 & 11,511 & 11,511 \\
$\mathrm{R}^{2}$ & 0.235 & 0.978 & 0.164 & 0.959 \\
\hline
\end{tabular}

Notes: Dependent variables are for column (A): normalized log loans; for column (B): log loans; for column (C): normalized real loans; and for column (D): real loans in EUR 1,000. Standard errors are clustered at the bank level and are stated in brackets. *, **, and *** indicate statistical significance at the $5 \%$, the $1 \%$, and the $0.1 \%$ level, respectively.

\section{Alternative control variables}

The following two tables provide evidence that the election effect is also robust to variations in the set of covariates used for analysis. Table 8 displays results for specifications that drop certain variables from the list of regressors, whereas specifications in table 9 are augmented with additional control variables, not used in the main empirical model. Again, to ease comparison, results for the benchmark specification are repeated in column (A) of these tables.

As is evident from columns (B) through (F) of table 8, the election effect remains significant at the $5 \%$ level if any of the control variables is excluded from the set of regressors. Results are somewhat weakened if we fail to control for district controls (column (F)), as the size of the election effect is roughly cut in half. Given that the analysis certainly benefits from controlling for variables that may impact lending decisions irrespective of electoral timing, we attach higher credibility to specifications that account for both bank-specific factors and districtlevel macroeconomic factors. We are nonetheless pleased that the election effect is found in all specifications and not the artificial result of bad control. Notably, 
Table 8. Alternative control variables: Fewer covariates

Dependent variable: Log loans normalized by total assets

\begin{tabular}{lcccccc}
\hline $\begin{array}{l}\text { Explanatory } \\
\text { variables }\end{array}$ & \multicolumn{7}{c}{ OLS regression coefficients } \\
& (Robust standard errors in brackets) \\
\cline { 2 - 7 } & (A) & $(\mathrm{B})$ & $(\mathrm{C})$ & $(\mathrm{D})$ & $(\mathrm{E})$ & $(\mathrm{F})$ \\
\hline Key regressors & & & & & & \\
$-E L E C_{s t}^{C} * B_{b}$ & $0.021^{* * *}$ & $0.018^{* * *}$ & $0.012^{*}$ & $0.010^{*}$ & $0.022^{* * *}$ & $0.011^{*}$ \\
& $(0.005)$ & $(0.005)$ & $(0.004)$ & $(0.004)$ & $(0.006)$ & $(0.004)$ \\
$-E L E C_{s t}^{C}$ & -0.005 & -0.004 & -0.003 & -0.002 & -0.002 & -0.002 \\
& $(0.004)$ & $(0.004)$ & $(0.003)$ & $(0.003)$ & $(0.004)$ & $(0.003)$ \\
Bank controls & Yes & - & Yes & - & Yes & - \\
District controls & Yes & Yes & - & - & Yes & - \\
State FE & Yes & Yes & Yes & Yes & - & - \\
Time FE & Yes & Yes & Yes & Yes & - & - \\
Bank type FE & Yes & Yes & Yes & Yes & Yes & Yes \\
\hline $\mathrm{N}$ & 11,511 & 11,511 & 15,666 & 15,666 & 11,511 & 15,666 \\
$\mathrm{R}^{2}$ & 0.235 & 0.219 & 0.225 & 0.212 & 0.114 & 0.046 \\
\hline
\end{tabular}

Notes: Time-varying explanatory variables are excluded from the vector of controls as indicated by "-". Standard errors are clustered at the bank level and are stated in brackets. *,**, and $* * *$ indicate statistical significance at the $5 \%$, the $1 \%$, and the $0.1 \%$ level, respectively.

the results even survive when excluding state and time fixed effects, which underscores the generality of the effect, elections have on lending.

To examine whether the further addition of covariates has a dampening effect on the $\delta_{1}$ estimates, we include a multitude of district-level control variables to the set of regressors. As results in table 9 demonstrate, neither information on local public debt, (un)employment, real earnings, nor firm creation have a notable impact on the election effect, with the latter remaining in a narrow interval of $1.9 \%$ to $2.2 \%$. Furthermore, none of the additional control variables have a statistically significant effect on lending themselves. Since some of these variables are unavailable for the time before 1998, we exclude them from the main specification to avoid needless reductions in sample size and the preclusion of analysis for most of the 1990s. Summing up, the documented election effect seems also not to be the the result of omitted-variable bias.

\section{Alternative definitions of the pre-election indicator}

The definition of the pre-election indicator employed for the main empirical specification is chosen to make sure that, conditional on the coarse annual bank data we have access to, the true pre-election year is correctly identified. To clarify this 
Table 9. Alternative control variables 2: Additional covariates Dependent variable: Log loans normalized by total assets

\begin{tabular}{|c|c|c|c|c|c|c|c|}
\hline \multirow[t]{2}{*}{$\begin{array}{l}\text { Explanatory } \\
\text { variables }\end{array}$} & \multicolumn{7}{|c|}{$\begin{array}{l}\text { OLS regression coefficients } \\
\text { (Robust standard errors in brackets) }\end{array}$} \\
\hline & (A) & (B) & (C) & (D) & (E) & (F) & (G) \\
\hline \multicolumn{8}{|l|}{ Key regressors } \\
\hline$-E L E C_{s t}^{C} * B_{b}$ & $\begin{array}{l}0.021 * * * \\
(0.005)\end{array}$ & $\begin{array}{l}0.021 * * * \\
(0.005)\end{array}$ & $\begin{array}{l}0.022 * * * \\
(0.005)\end{array}$ & $\begin{array}{l}0.022 * * * \\
(0.005)\end{array}$ & $\begin{array}{l}0.022 * * * \\
(0.005)\end{array}$ & $\begin{array}{l}0.019 * * \\
(0.006)\end{array}$ & $\begin{array}{l}0.019 * * \\
(0.006)\end{array}$ \\
\hline - $E L E C_{s t}^{C}$ & $\begin{array}{c}-0.005 \\
(0.004)\end{array}$ & $\begin{array}{c}-0.005 \\
(0.004)\end{array}$ & $\begin{array}{c}-0.005 \\
(0.004)\end{array}$ & $\begin{array}{c}-0.005 \\
(0.004)\end{array}$ & $\begin{array}{c}-0.005 \\
(0.004)\end{array}$ & $\begin{array}{c}-0.004 \\
(0.004)\end{array}$ & $\begin{array}{c}-0.004 \\
(0.004)\end{array}$ \\
\hline \multicolumn{8}{|l|}{ Bank controls } \\
\hline - Total assets & Yes & Yes & Yes & Yes & Yes & Yes & Yes \\
\hline - Capital ratio & Yes & Yes & Yes & Yes & Yes & Yes & Yes \\
\hline \multicolumn{8}{|l|}{ District controls } \\
\hline - Population & Yes & Yes & Yes & Yes & Yes & Yes & Yes \\
\hline - Population growth & Yes & Yes & Yes & Yes & Yes & Yes & Yes \\
\hline - Real GDP & Yes & Yes & Yes & Yes & Yes & Yes & Yes \\
\hline - Real GDP growth & Yes & Yes & Yes & Yes & Yes & Yes & Yes \\
\hline - Public debt & - & Yes & - & - & - & - & Yes \\
\hline - Employment & - & - & Yes & - & - & - & Yes \\
\hline - Unemployment & - & - & - & Yes & - & - & Yes \\
\hline - Real earnings & - & - & - & - & Yes & - & Yes \\
\hline - Firm creation & - & - & - & - & - & Yes & Yes \\
\hline State FE & Yes & Yes & Yes & Yes & Yes & Yes & Yes \\
\hline Time FE & Yes & Yes & Yes & Yes & Yes & Yes & Yes \\
\hline Bank type FE & Yes & Yes & Yes & Yes & Yes & Yes & Yes \\
\hline $\mathrm{N}$ & 11,511 & 11,355 & 11,480 & 11,511 & 11,511 & 9,660 & 9,538 \\
\hline $\mathrm{R}^{2}$ & 0.235 & 0.236 & 0.234 & 0.234 & 0.234 & 0.219 & 0.223 \\
\hline
\end{tabular}

Notes: Combinations of time-varying explanatory variables are added to the vector of controls as indicated by "Yes". Standard errors are clustered at the bank level and are stated in brackets. *, **, and $* * *$ indicate statistical significance at the $5 \%$, the $1 \%$, and the $0.1 \%$ level, respectively.

point, if an election takes place in, say, January, pre-election lending will have been extended in the previous year. Hence, the pre-election indicator from the main empirical model indicates an election in either the last two quarters of the current year or the first two quarters of the following year.

Table 10 presents in column (A) results from the benchmark specification and in columns (B) and (C) results for two alternative definitions of the pre-election indicator: P2, presented in (B), indicates an election in the current calendar year and P3, in (C) indicates an election in the following calendar year. Reassuringly, the pre-election lending effect is still highly significant, but reduced in size, which makes sense given that in both cases we are less effectively capturing the period actually affected by the electoral event. 
Table 10. Alternative pre-election indicators

Dependent variable: Log loans normalized by total assets

\begin{tabular}{lccc}
\hline \multirow{2}{*}{$\begin{array}{l}\text { Explanatory } \\
\text { variables }\end{array}$} & \multicolumn{3}{c}{ OLS regression coefficients } \\
& (Robust standard errors in brackets) \\
\cline { 2 - 4 } & (A) & (B) & $(\mathrm{C})$ \\
\hline Key regressors & $0.021^{* * *}$ & $0.013^{*}$ & $0.017^{* *}$ \\
$-E L E C_{s t}^{C} * B_{b}$ & $(0.005)$ & $(0.006)$ & $(0.005)$ \\
$-E L E C_{s t}^{C}$ & -0.005 & -0.007 & -0.002 \\
& $(0.004)$ & $(0.005)$ & $(0.004)$ \\
Bank controls & Yes & Yes & Yes \\
District controls & Yes & Yes & Yes \\
State FE & Yes & Yes & Yes \\
Time FE & Yes & Yes & Yes \\
Bank type FE & Yes & Yes & Yes \\
\hline Pre-election indicator & P1 & P2 & P3 \\
\hline $\mathrm{N}$ & 11,511 & 11,511 & 11,551 \\
$\mathrm{R}^{2}$ & 0.235 & 0.235 & 0.235 \\
\hline
\end{tabular}

Notes: Abbreviations are as follows: P1 is the pre-election indicator from our main empirical specification and indicates an election in either the last two quarters of the current year or the first two quarters of the following year. P2 indicates an election in the current calendar year. P3 indicates an election in the following calendar year. Standard errors are clustered at the bank level. Empirical pvalues are stated in brackets. Boldfaced numbers indicate statistical significance at the $5 \%$ level.

\subsection{Alternative sample compositions}

Alternative panel balancedness

The main results from section 6 come from the entire available data sample. As mentioned in section 4.1, our bank data is quite unbalanced since many banks, though having been active in the market, only start to be documented in the database and hence enter the sample some time after 1993. At the same time, the sample is subject to mild attrition that is due to mergers of banks within one class (savings or cooperative banks). To ensure that results are not driven by these data characteristics, we re-estimate model 1 on a completely balanced panel. This alternative sample consists of 289 savings banks (4,913 bank years) 
Table 11. Alternative sample compositions

Dependent variable: Log loans normalized by total assets

\begin{tabular}{|c|c|c|c|c|c|c|c|c|c|c|}
\hline \multirow[t]{2}{*}{$\begin{array}{l}\text { Explanatory } \\
\text { variables }\end{array}$} & \multicolumn{10}{|c|}{$\begin{array}{l}\text { OLS regression coefficients } \\
\text { (Robust standard errors in brackets) }\end{array}$} \\
\hline & (A) & (B) & (C) & (D) & (E) & $(F)$ & (G) & (H) & (I) & $(J)$ \\
\hline \multicolumn{11}{|l|}{ Key regressor } \\
\hline - $E L E C_{s t}^{C} * B_{b}$ & $\begin{array}{l}0.021 * * * \\
(0.005)\end{array}$ & $\begin{array}{c}0.023^{*} \\
(0.009)\end{array}$ & $\begin{array}{c}0.026 * * \\
(0.010)\end{array}$ & $\begin{array}{c}0.020 * * \\
(0.007)\end{array}$ & $\begin{array}{l}0.020 * * * * \\
(0.005)\end{array}$ & $\begin{array}{l}0.021 * * * \\
(0.005)\end{array}$ & $\begin{array}{c}0.030 * * \\
(0.006)\end{array}$ & $\begin{array}{c}0.016^{*} \\
(0.006)\end{array}$ & $\begin{array}{l}0.024 * * * \\
(0.005)\end{array}$ & - \\
\hline$-E L E C_{s t}^{C}$ & $\begin{array}{l}-0.005 \\
(0.004)\end{array}$ & $\begin{array}{l}-0.006 \\
(0.008)\end{array}$ & $\begin{array}{c}-0.002 \\
(0.004)\end{array}$ & $\begin{array}{l}-0.000 \\
(0.004)\end{array}$ & $\begin{array}{l}-0.004 \\
(0.004)\end{array}$ & $\begin{array}{l}-0.005 \\
(0.004)\end{array}$ & $\begin{array}{l}-0.008 \\
(0.004)\end{array}$ & $\begin{array}{c}-0.002 \\
(0.005)\end{array}$ & $\begin{array}{c}-0.006 \\
(0.004)\end{array}$ & $\begin{array}{c}0.011^{* * *} \\
(0.004)\end{array}$ \\
\hline Bank controls & Yes & Yes & Yes & Yes & Yes & Yes & Yes & Yes & Yes & Yes \\
\hline District controls & Yes & Yes & Yes & Yes & Yes & Yes & Yes & Yes & Yes & Yes \\
\hline State FE & Yes & Yes & Yes & Yes & Yes & Yes & Yes & Yes & Yes & Yes \\
\hline Time FE & Yes & Yes & Yes & Yes & Yes & Yes & Yes & Yes & Yes & Yes \\
\hline Bank type FE & Yes & Yes & Yes & Yes & Yes & Yes & Yes & Yes & Yes & Yes \\
\hline Balanced panel & - & Yes & - & - & - & - & - & - & - & - \\
\hline Year range & - & - & $90-99$ & 00-09 & - & - & - & - & - & - \\
\hline Dropped states & - & - & - & - & East & City & Idio & BV & - & - \\
\hline Dropped banks & - & - & - & - & - & - & - & - & Largest & Coop \\
\hline $\mathrm{N}$ & 11,511 & 5,280 & 3,731 & 7,780 & 10,931 & 11,380 & 8,963 & 8,819 & 10,177 & 5,211 \\
\hline $\mathrm{R}^{2}$ & 0.235 & 0.114 & 0.341 & 0.202 & 0.088 & 0.237 & 0.270 & 0.270 & 0.259 & 0.378 \\
\hline
\end{tabular}

Notes: Abbreviations are as follows: "_" indicates choices of our main specification. Years: 90=1990; 99=1999; $00=2000 ; 09=2009$. East $=$ East German states; City $=$ City States (Berlin, Bremen, Hamburg); Idio=States on idiosyncratic time trends (Hesse, Lower Saxony, and Schleswig-Holstein); BV=Bavaria (state with most prominent election effect). Largest $=$ Banks in the highest decile of loan sum sizes; Coop=Cooperative banks. Standard errors are clustered at the bank level and are stated in brackets. * **, and ${ }^{* * *}$ indicate statistical significance at the $5 \%$, the $1 \%$, and the $0.1 \%$ level, respectively.

and 177 cooperative banks (3,009 bank years) and represents roughly $42 \%$ of the original sample. ${ }^{21}$

While column (A) of table 11 shows the results for the benchmark specification, it is evident from column (B) that the election effect proves to be immune to even such extreme reductions in sample size: Based on banks that remained in the sample from 1993 to 2009, the estimated increase in savings bank lending amounts to $2.3 \%$ and is statistically significant at the $5 \%$ level.

\section{Alternative time intervals}

To investigate the stability of the election effect across time, we divide the whole sample into two panel sets of roughly equal size, with the first covering the years

\footnotetext{
${ }^{21}$ Note that in additional robustness checks not reported here, we have also experimented with earlier and later cut-off points than 1993 to create balanced panels. Estimations based on these yield comparable conclusions.
} 
between 1990 and 1999 and the second covering the time between 2000 and 2009. As can be seen in columns (C) and (D) of table 11, lending increases of at least $2 \%$ occur in both the 1990 s and the 2000 s and are, hence, unlikely to be driven by any temporal anomalies not captured by the set of covariates and time dummies. The fact that the election effect for the later time interval is estimated with increased precision, is most likely attributable to the higher number of bank years: Recall that the representativeness of Hoppenstedt's cooperative bank data greatly improves during the early 2000s, as many smaller banks whose balance sheets were not collected before, are added to the sample around this time. On this account, it is encouraging that the election effect is robust to this kind of sample selectivity as well.

\section{Alternative regional compositions}

To further assess the generality of results, we apply model 1 to four sub-samples that individually exclude certain sets of states from the main sample: the East German states; the three city states (Berlin, Bremen, and Hamburg); the three states that are on idiosyncratic time trends (Hesse, Lower Saxony, and SchleswigHolstein, see section 4.4); and Bavaria which happens to be the state for which the election effect is most pronounced. As columns (E) through (H) of table 11 show, these changes leave the main conclusions intact, suggesting that they are not driven by regional effects. While results are almost unchanged by the exclusion of city states and the former GDR territory, they become even stronger when ignoring the states whose lending trends appear out of sync with the rest of Germany. The fact that the effect decreases when Bavaria is excluded, is likely explained by the role of incumbent entrenchment, which - as argued in section 6 appears to be a precondition for the ability of politicians to manipulate bank policies. Considering that elections in Bavaria are historically much less contested than those in other states, the observed differences may well be driven by this feature. $^{22}$

\footnotetext{
${ }^{22}$ This pattern holds for all indicators we constructed to capture the degree of political competition in a district. To give one example, $8 \%$ of all municipal elections of legislative bodies in Germany are lost by the incumbent party, whereas Bavaria (3\%) is characterized by considerably higher party dominance.
} 


\section{Alternative composition of banks}

In a next step, we assure that the results are not driven by outliers and remove all banks whose loan sums exceed EUR 2 billion, effectively shedding the upper decile of banks from the sample. These are mainly banks that operate in large cities such as Cologne, Munich, and Frankfurt. As results in column (I) of table 11 show, effect sizes, if anything, even slightly increase, suggesting that the observed phenomenon is not limited to a few "power players" in the banking sector.

In yet another deviation from the main specification, column $(\mathrm{J})$ contains results from a sample without cooperative banks. As argued in section 6, we believe that the existence of a control group improves identification of the causal effects. However, to provide evidence that results are not driven by cooperativebank-specific factors, we re-estimate the election effect when only exploiting cross-sectional and time differences between savings banks. Overall, the main results are confirmed, even though effect sizes appear to be somewhat smaller. The electoral lending cycle, as estimated without a control group of politically unconnected banks, is visualized in figure 7 and roughly follows the pattern depicted in figure 4, with a significant spike just before an election and some weak evidence for credit crunching in the years thereafter.

\section{Conclusion}

We provide causal evidence for electorally induced lending cycles in Germany a country that is often praised for its strong institutional environment. German law stipulates the active involvement of county-level politicians in the management of local savings banks. Exploiting the rich cross-sectional and intertemporal variation in our data, we find that - consistent with our predictions - politically motivated excess lending only occurs before county election, only in counties in which elections are held at this point in time, and only for savings banks as opposed to politically independent cooperative banks. These lending distortions are economically meaningful and are most pronounced in counties where the ruling party is deeply entrenched (providing the ability to affect bank decisions) but faces a close re-election race (providing the incentive to resort to inefficient policies). The latter result adds to the findings of Akhmedov and Zhuravskaya (2004) who show that transparency, voter awareness, and the maturity of a democracy 
Figure 7. Results for prediction 3

The lending cycle for municipal elections (without cooperative banks)

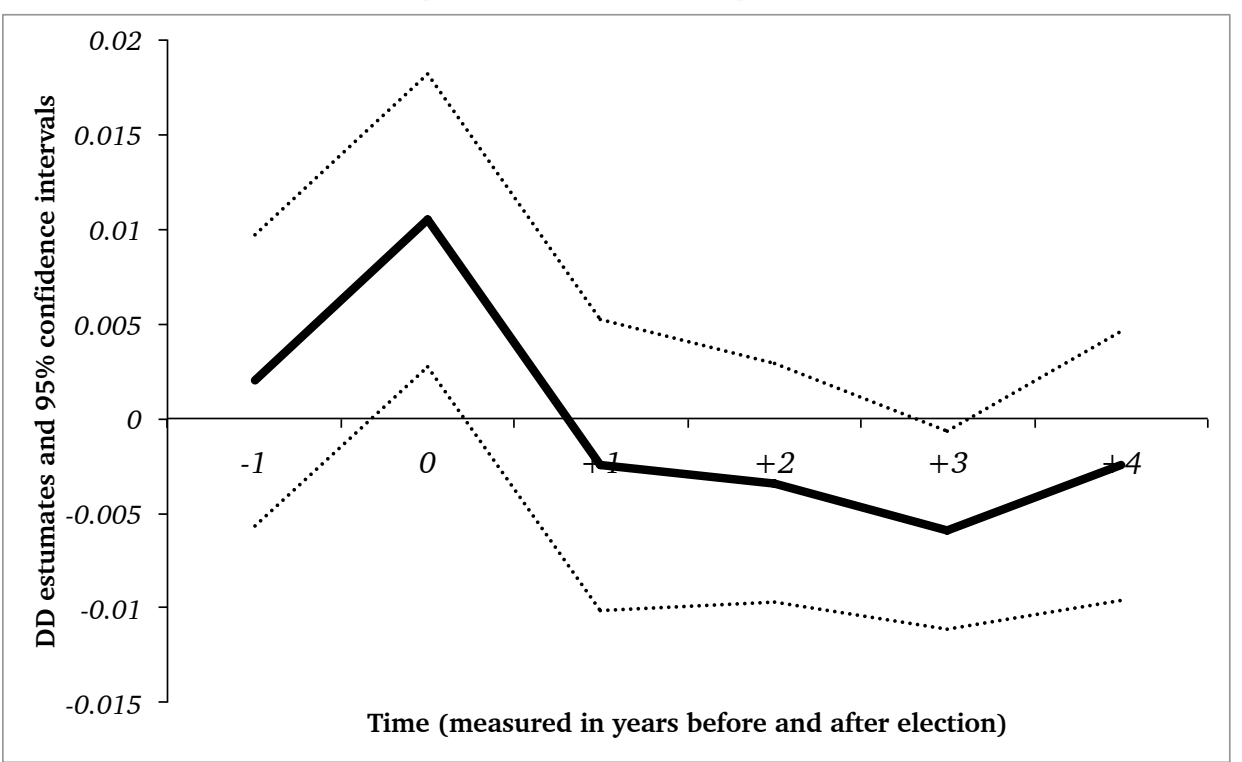

Notes: Results are for the main empirical specification (see section 5). The solid line depicts estimates of the effect of municipal elections on savings bank lending, when no control group of cooperative banks is used. Dottet lines indicate $95 \%$ confidence intervals. Time is measured on the abscissa.

are important in determining the scope for opportunistic political cycles. Since all of these factors are arguably in good order in Germany, the results highlight that continued actual political competition - and not only potential competition guaranteed by strong institutions - is vital in keeping political tinkering in check.

The election-induced lending effects are very robust to alternative empirical specifications (the choice of estimators, the mode of statistical inference, the choice of controls, the definition of key variables, and the composition of the sample), which emphasizes the generality of our findings. Furthermore, the fact that we control for macroeconomic variables (such as GDP in levels and in growth rates) at the district level, and that we do not find effects for state elections or among cooperative banks, renders the results unlikely to be driven by credit demand, underlining the politically induced margin of distortion of the observed pattern.

While the latter conclusion is potentially worrisome on its own - especially given the vital role savings banks play in the German economy - future research would certainly benefit from a better understanding of the social costs of interfering with bank operations for political gain. A natural measure would be 
to compare credit defaults between pre-election and post-election credits. Comprehensive loan-level data that would allow to answer these questions does in principle exist, but is generally not available to researchers. If access to this kind of data were granted in the future, further extensions of this research would be possible: For instance, it would be helpful to understand whether the election effect works via the extensive (additional credits are extended) or intensive (larger credits are extended) margin and whether politicians target short-term or long-term credit to name just two dimensions of interest. 


\section{References}

Akhmedov, A. and Zhuravskaya, E. (2004). Opportunistic political cycles: Test in a young democracy setting. Quarterly Journal of Economics, 119, 1301-1338. 3,40

Alesina, A., Roubini, N. and Cohen, G. D. (1997). Political cycles and the macroeconomy. MIT Press. 3

Angrist, J. D. and Pischke, J.-S. (2009). Mostly harmless econometrics. Princeton University Press. 15, 30, 33

Atkinson, A. B. and Stiglitz, J. E. (1980). Lectures on public economics. McGraw Hill. 1

Bertrand, M., Duflo, E. and Mullainathan, S. (2004). How much should we trust differences-in-differences estimates? Quarterly Journal of Economics, 119 (1), 249-275. 30, 31

—, Kramarz, F., Schoar, A. and Thesmar, D. (2007). Politicians, firms and the political business cycle: Evidence from France. mimeo. 3

Cameron, A. C. and Miller, D. L. (2010). Robust inference with clustered data. mimeo. 30, 33

— and Trivedi, P. K. (2010). Microeconometrics using Stata. Stata Press. 31, 32

Carvalho, D. (2012). The real effects of government-owned banks. Journal of Finance, forthcoming. 1, 4

Cole, S. A. (2009). Fixing market failures or fixing elections? elections, banks and agricultural lending in India. American Economic Journal: Applied Economics, 1(1), 219-250. 1, 4

Dinç, I. S. (2005). Politicians and banks: Political influences on governmentowned banks in emerging markets. Journal of Financial Economics, 77 (2), 453-479. 1, 4, 21

Engerer, H. (2006). Vom Dreisäulensystem zum Baustein des Europäischen Hauses: Wandel von Eigentum und Wettbewerb im deutschen Bankensektor. DIW Vierteljahreshefte zur Wirtschaftsforschung, 75 (4), 11-32. 8 
Fischer, M., Hainz, C., Rocholl, J. and Steffen, S. (2011). Government guarantees and bank risk taking incentives. Working Paper EMTS. 7

Gropp, R., Grundl, C. and Guttler, A. (2011). The impact of public guarantees on bank risk taking: Evidence from a natural experiment. Working Paper Tilburg University. 7

Gruber, J. (1994). The incidence of mandated maternity benefits. American Economic Review, 84 (3), 622-641. 20

Güde, U. (1995). Geschäftspolitik der Sparkassen: Grundlagen und aktuelle Probleme. Deutscher Sparkassenverlag Stuttgart. 7

Guinnane, T. W. (2002). Delegated monitors: Large and small: Germany's banking system, 1800-1914. Journal of Economic Literature, 40, 73-124. 6

Hakenes, H. and Schnabel, I. (2011). Capital regulation, bank competition, and financial stability. Economic Letters, 113 (3), 256-258. 8

Khwaja, A. I. and Mian, A. (2005). Do lenders favor politically connected firms? rent provision in an emerging financial market. Quarterly Journal of Economics, 120 (4), 1371-1411. 1, 4, 31

La Porta, R., Lopez de Silanes, F. and Shleifer, A. (2002). Government ownership of banks. Journal of Finance, 57 (1), 265-301. 1, 3

MacRae, D. C. (1977). A political model of the business cycle. Journal of Political Economy, 85 (2), 239-263. 3

Mitchell, D. M. and Willett, K. (2006). Local economic performance and election outcomes. Atlantic Economic Journal, 34 (2), 219-232. 3

Nordhaus, W. D. (1975). The political business cycle. Review of Economic Studies, 42 (2), 169-190. 3

Peltzman, S. (1987). Economic conditions and gubernatorial elections. American Economic Review, 77(2), 293-297. 1, 8

Sapienza, P. (2004). The effects of government ownership on bank lending. Journal of Financial Economics, 72 (2), 357-384. 1, 3 
Schlierbach, H. (2003). Das Sparkassenrecht in der Bundesrepublik Deutschland. Deutscher Sparkassenverlag Stuttgart. 7

Schneider, C. (2010). Fighting with one hand tied behind the back: Political budget cycles in the West German states. Public Choice, 142 (1), 125-150. 3

Schwartz, A. J. (2009). Origins of the financial market crisis of 2008. Cato Journal, 29(1), 19-23. 1

Shleifer, A. and Vishny, R. W. (1994). Politicians and firms. Quarterly Journal of Economics, 109 (4), 995-1025. 1

Smart, M. and Sturm, D. M. (2007). Do politicians respond to reelection incentives? evidence from gubernatorial elections. Working Paper LSE. 1, 8

Wolfers, J. (2007). Are voters rational? evidence from gubernatorial elections. Working Paper Wharton School. 1, 8 